University of Wollongong

Research Online

Faculty of Business - Papers (Archive)

Faculty of Business and Law

$1-1-2019$

Duration of equity overvaluation and managers' choice to use aggressive underlying earnings disclosure and accrual-based earnings management: Australian evidence

Yiru Yang

University of Wollongong, yy449@uowmail.edu.au

Indra Abeysekera

Charles Darwin University, indraa@uow.edu.au

Follow this and additional works at: https://ro.uow.edu.au/buspapers

Part of the Business Commons

Research Online is the open access institutional repository for the University of Wollongong. For further information contact the UOW Library: research-pubs@uow.edu.au 


\title{
Duration of equity overvaluation and managers' choice to use aggressive underlying earnings disclosure and accrual-based earnings management: Australian evidence
}

\begin{abstract}
This paper examines whether equity overvaluation duration influences managers' choice of different earnings management mechanisms and how corporate governance and the Australian Securities and Investment Commission's underlying earnings disclosure guidelines influence managers' choices. The study samples Australian Securities Exchange 200 firms from 2009 to 2016 . Findings show that on average, firms more likely engage in accrual-based earnings management in the early overvaluation stage. In later stages, firms more likely disclose underlying earnings aggressively to sustain overvaluation. Additionally, firms with a high proportion of independent directors on the board prefer to disclose underlying earnings aggressively to sustain the equity overvaluation; firms with a low proportion of independent directors prefer both accrual-based earnings management and aggressive underlying earnings disclosure to sustain the overvaluation. Moreover, firms that conform to the Commission's underlying earnings disclosure guidelines use neither accrual-based earnings management nor aggressive underlying earnings disclosure to sustain overvaluation, but non-conforming firms use both mechanisms.

Disciplines

Business

Publication Details

Yang, Y. \& Abeysekera, I. (2019). Duration of equity overvaluation and managers' choice to use aggressive underlying earnings disclosure and accrual-based earnings management: Australian evidence. Journal of Contemporary Accounting and Economics, 15 (2), 167-185.
\end{abstract}

This journal article is available at Research Online: https://ro.uow.edu.au/buspapers/1573 
Duration of Equity Overvaluation and Managers' Choice to Use Aggressive

Underlying Earnings Disclosure and Accrual-based earnings Management:

\title{
Australian Evidence
}

\author{
Yiru Yang, ${ }^{a}$ Indra Abeysekera ${ }^{\mathrm{b}}$ \\ ${ }^{\text {a }}$ University of Wollongong, Australia \\ ${ }^{\mathrm{b}}$ Charles Darwin University, Australia
}

${ }^{a}$ Corresponding author. Tel.: +61 423721342. Email address: yy449@uowmail.edu.au. Postal address: School of Accounting, Economics and Finance, Northfields Ave, Wollongong NSW 2522, Australia.

b Tel: +61 417405399 Email address: indraabeysekera@gmail.com. Postal address: Charles Darwin University, College of Business and Law, 21 Kitchener Drive, Darwin NT 0800, Australia. 


\title{
Duration of Equity Overvaluation and Managers' Choice to Use Aggressive Underlying Earnings Disclosure and Accrual-based earnings Management: Australian Evidence
}

\begin{abstract}
This paper examines whether equity overvaluation duration influences managers' choice of different earnings management mechanisms and how corporate governance and the Australian Securities and Investment Commission's underlying earnings disclosure guidelines influence managers' choices. The study samples Australian Securities Exchange 200 firms from 2009-2016. Findings show that on average, firms more likely engage in accrual-based earnings management in the early overvaluation stage. In later stages, firms more likely disclose underlying earnings aggressively to sustain overvaluation. Additionally, firms with a high proportion of independent directors on the board prefer to disclose underlying earnings aggressively to sustain the equity overvaluation; firms with a low proportion of independent directors prefer both accrual-based earnings management and aggressive underlying earnings disclosure to sustain the overvaluation. Moreover, firms that conform to the Commission's underlying earnings disclosure guidelines use neither accrual-based earnings management nor aggressive underlying earnings disclosure to sustain overvaluation, but non-conforming firms use both mechanisms.
\end{abstract}

\section{JEL classification: M41}

Key words: underlying earnings disclosure, accrual-based earnings management, equity overvaluation, corporate governance, ASIC underlying earnings guideline 


\section{Introduction}

Because earnings and their growth are key components determining firm value, managers are highly motivated to increase earnings and their growth expectations, ultimately inflating firm value to increase stock prices (Adams et al., 2009; Badertscher, 2011; Brown and Caylor, 2005; Graham et al., 2005). Evidence shows that managers' wealth increases as a firm's stock price increases, because their compensation is associated with the stock price via stock performance-based incentives (Bergstresser and Philippon, 2006). Moreover, managers' job security in the executive labour market typically increases with strong performance of the firm's stock, with a manager being less likely to lose a job when the stock is performing well (Jensen, 2005). These motivations typically stimulate managers to strive for higher stock prices. Studies have found that managers are fully aware of opportunities to manage earnings, and earnings management is the main approach used by managers to obtain their desired economic outcomes because investors are unlikely to uncover earnings management (Badertscher, 2011; Nelson et al., 2002, 2003; Xie, 2001). However, the aggregate shareholder value destroyed by earnings management far exceeds that of high-profile fraud cases (Badertscher, 2011; Graham et al., 2005).

Jensen's (2005) agency theory of overvalued equity suggests that when a firm's stock price becomes overvalued, the firm maintains the overvaluation by participating in a variety of earnings management choices. Previous research has provided empirical evidence consistent with Jensen's (2005) conjecture. For instance, Efendi et al. (2007) demonstrated that firms exhibiting signs of overvaluation in the years prior to engaging in non-statutory earnings management increase managers' stock compensation incentives to sustain the overvalued stock prices. Badertscher (2011) indicated that overvaluation is an important determinant of earnings management decisions. This author found that managers participate in accrual-based earnings management in the early stage of overvaluation, then move to real activities earnings management to sustain the overvaluation of the equity; in the later stages, managers tend to engage in non-generally accepted accounting principle (non-GAAP) earnings management. Although several studies have investigated the correlation between overvaluation of equity and earnings management, there remains limited empirical 
evidence for the correlation between the duration of overvaluation and management's choice of alternative earnings management mechanisms (Badertscher, 2011).

This paper initially examines whether the duration of overvaluation affects managers' decisions to use different earnings management mechanisms. It investigates whether the duration of equity overvaluation affects managers' choice to use accrual-based earnings management and aggressive underlying earnings disclosure. The results demonstrate that, on average, in the early stage of overvaluation, managers are more likely to use accrual-based earnings management. In the later stage, they run out of accrual-based earnings management choices and resort to aggressive underlying earnings disclosure to maintain overvaluation. Second, this paper investigates whether corporate governance influences managers' choice of different earnings management mechanisms. The results show that firms with a high proportion of independent directors on the board do not choose accrual-based earnings management to sustain overvaluation but instead prefer to disclose underlying earnings aggressively in the later stage of overvaluation. Firms with a low proportion of independent directors are more likely to use both earnings management mechanisms to sustain overvaluation. Finally, this paper examines the effects of the Australian Securities and Investment Commission (ASIC) underlying earnings disclosure guidelines on management's choice of earnings management mechanisms. Because the ASIC guidelines are voluntary, we examine the influence of overvaluation on the choice of earnings management mechanisms by firms that conform to the guidelines and by those that do not. We find that firms that conform to the ASIC underlying earnings disclosure guidelines do not use either accrual-based earnings management or aggressive underlying earnings disclosure to sustain overvaluation. However, firms that do not conform to the ASIC underlying earnings disclosure guidelines are more likely to use both accrual-based earnings management and aggressive underlying earnings disclosure to sustain overvaluation.

The additional test investigates whether the constraints of using accrual-based earnings management encourage managers to engage in aggressive underlying earnings disclosure. This study finds that equity-overvalued firms with a high level of accrual-based earnings management constraints only engage in aggressive underlying earnings disclosure to maintain overvaluation. 
This paper contributes to the literature on equity overvaluation and earnings management by examining whether managers alternate between accrual-based earnings management and aggressive underlying earnings disclosure to sustain overvaluation. Three previous studies have examined the association between aggressive non-statutory earnings reporting (pro forma earnings) with within-statutory earnings management techniques (accrual-based earnings management and/or real activities earnings management) (Black et al., 2014; Doyle et al., 2013; Elshafie et al., 2010). All three studies found that managers alternate between accrual-based earnings management and aggressive non-GAAP earnings reporting. However, they did not examine whether the duration of equity overvaluation incentives affects managers' choice to use accrual-based earnings management and aggressive underlying earnings disclosure. Second, although previous studies have examined the relationship between non-GAAP earnings and accrual-based earnings management using the absolute value of accrual-based earnings management, this paper examines whether managers use aggressive underlying earnings disclosure and income-increasing accrual-based earnings management alternatively or simultaneously. Third, this paper empirically tests Jensen's (2005) agency theory of overvalued equity. Badertscher (2011) examined overvaluation and managers' choice of non-statutory earnings management, and found that overvalued firms are more likely to engage in non-GAAP earnings management than are firms that are not overvalued. However, Badertscher (2011) defined non-GAAP earnings management as firms that identified restatement announcements that raised questions about the quality of financial reporting. It is unclear whether managers use aggressive non-GAAP earnings reporting as an earnings management tool to substitute for other earnings management tools to sustain overvalued equity. This paper extends Badertscher (2011) by investigating how the duration of overvalued firms affects managers' use of accrual-based earnings management and aggressive underlying earnings (similar to non-GAAP earnings in the US) disclosure. Finally, this paper is the first to examine whether corporate governance and ASIC's underlying earnings disclosure guidelines influence managers' decision-making on using different earnings management techniques to sustain overvaluation. We extend the results of Baderscher (2011) because we find not only that on average, managers use earnings management mechanisms alternatively to sustain the equity overvaluation but also that if firms have a lower proportion of independent directors or do not conform to the ASIC underlying 
earnings guidelines, then managers prefer to use earnings management mechanisms simultaneously to sustain the equity overvaluation.

We have organised the paper as follows. Section 2 provides a literature review. Section 3 develops the hypotheses. Section 4 describes the research design of this study. Section 5 presents the descriptive statistics, Pearson and Spearman correlations, and regressions results. Section 6 provides the additional test, and Section 7 concludes.

\section{Literature review}

\subsection{Underlying earnings}

Underlying earnings are calculated based on the judgements of the preparer and reflect the core/recurring business activities of reporting firms. They are voluntarily reported earnings on a basis other than the International Financial Reporting Standards (IFRS), or consistent with IFRS and then adjusted by firm managers (Australian Institute of Company Directors [AICD] and Financial Services Institute of Australasia [FINSIA], 2009). Firms use various labels to describe underlying earnings, including pro forma earnings; normalised earnings; underlying earnings before interest and taxes (EBIT); underlying earnings before interest, taxes, depreciation, and amortisation (EBITDA); earnings before exceptional items; results excluding exceptional items; results before non-recurring items; results before significant items; results before special items; results before specific items; adjusted earnings before interest, tax, depreciation, and amortisation; or adjusted operating earnings (AICD and FINSIA, 2009; Ernst and Young, 2007). The underlying earnings used in this paper represent all such terms because they provide an alternative to statutory earnings. Although there is no general agreement on computing underlying earnings, significant non-recurring items and IFRS-driven unrealised gains and losses are generally often excluded (AICD and FINSIA, 2009).

The adoption of underlying earnings is a common phenomenon in Australian firms. For example, Woodside Petroleum Limited's 2012 annual report documented that 'underlying net profit after tax was \$2,061 million, which was a $25 \%$ increase on the 2011 figure' (Woodside Petroleum, 2012, p. 4). Boral Limited documented a net statutory loss of $\$ 91$ million, whereas underlying profits after tax was a positive $\$ 132$ 
million in its 2010 annual report (Boral, 2010, p. 23). A study conducted by KPMG in 2009 found that $84 \%$ of firms on the ASX 100 Index presented underlying earnings as a response to growing dissatisfaction with statutory earnings as representative of firms' actual economic performance (KPMG, 2009). In 2012, 32 of 50 ASX Index firms chose to report financial results using underlying earnings of economic performance in addition to statutory earnings (KPMG, 2013). Recently, investors have focussed more on underlying earnings than on conventional statutory earnings, because underlying earnings are considered a proxy for a firm's ongoing profitability, an approach that is useful for evaluation (AICD and FINSIA, 2009; KPMG, 2009).

Previous studies have found that managers can use their discretion in defining nonstatutory earnings (i.e., pro forma earnings) in an aggressive manner, considering some actual recurring expenses non-recurring expenses to exclude for current earnings determination, resulting in a firm with favourable pro forma earnings in the context of the US (Bowen et al., 2005; Doyle et al., 2003, 2013; McVay et al., 2006). By aggressively defining the pro forma earnings (shifting recurring expenses to nonrecurring items to make non-statutory earnings higher than GAAP earnings), managers can achieve their personal interests with fewer costs than with real activities and accruals-based earnings management. The joint policy guidance paper produced by the Australian Institute of Company Directors (AICD) and Financial Services Institute of Australasia (FINSIA) argues that a long lead time in producing financial statements makes non-statutory reporting necessary (AICD and FINSIA, 2009). The publication of non-statutory reporting is termed underlying earnings, presented with a reconciliation between statutory earnings and underlying earnings (AICD and FINSIA, 2009; Sek and Taylor, 2011). As explained by the AICD and FINSIA (2009) report, underlying earnings represent statutory profits adjusted to present a directors' assessment of the results of the ongoing activities of the firm (p. 7). Australian Securities and Investment Commission (ASIC) Regulatory Guidance 230 provides the following statement in relation to non-IFRS (i.e., non-statutory profits) financial information calculation: "A clear explanation should be provided about how the nonIFRS financial information is calculated" (ASIC, 2011b, p. 18). It further states in relation to reconciliation, "A reconciliation between the non-IFRS and IFRS financial information should be provided, separately itemising and explaining each significant adjustment. When reconciling items are components of IFRS financial information, 
they should be capable of being reconciled to the financial report. When a reconciling item cannot be extracted directly from the financial report, the reconciliation should show how the figure is calculated. When comparative non-IFRS financial information is presented for a previous period, a reconciliation to the corresponding IFRS financial information should be provided for that previous period" (ASIC, 2011b, p. 18). In implementing the guideline in practice, for instance, the BHP 2017 Annual Report states under "Alternative performance measures" that "we use various alternate performance measures to reflect our underlying performance. Our two primary measures of performance are Underlying attributable profit and Underlying EBITDA. These measures, and other alternate performance measures, are reconciled below and defined in section 1.12.5" (BHP, 2017, p. 74, first paragraph).

There is no specific (Auditing Standard) requirement for external auditors "to audit" underlying profits because these are non-IFRS profits. However, if a Disclosure Reconciliation of Underlying Profits to Statutory Profits is presented, the auditor must check the reasonableness of the reconciliation. In addition, ASA 720 The Auditor's Responsibilities Relating to Other Information addresses financial and nonfinancial information presented in Other Information (e.g., Annual Report) versus the Financial Report (Financial Statements) as follows:

Paragraph 14 (p. 9). The auditor shall read the other information and, in doing so,

a. Consider whether there is a material inconsistency between the other information and the financial report. As the basis for this consideration, the auditor shall, to evaluate their consistency, compare selected amounts or other items on other information (that are intended to be the same as, to summarise, or to provide greater detail about, the amounts or other items in the financial report) with such amounts or other items in the financial report; and (Ref: Para. A25-A29)

b. Consider whether there is a material inconsistency between the other information and the auditor's knowledge obtained in the audit, in the context of audit evidence obtained and conclusions reached in the audit (Ref: Para. A30-A36).

Paragraph 15 (p. 9). While reading the other information in accordance with paragraph 14 of this Auditing Standard, the auditor shall remain alert for indications that the other information not related to the financial report or the auditor's 
knowledge obtained in the audit appears to be materially misstated (Ref: Para. A24, A37-A38).

Also applicable is Scope of ASA 720 The Auditor's Responsibilities Relating to Other Information, per paragraphs 1-9 and the Objectives per paragraph 11 of the ASA720 Auditing Standard. Note paragraphs 2 and 3:

Paragraph 2 (p. 7): This Auditing Standard is written in the context of an audit of a financial report by an independent auditor. Accordingly, the objectives of the auditor in this Auditing Standard are to be understood in the context of the overall objectives of the auditor as stated in paragraph 11 of ASA 200. The requirements in the Australian Auditing Standards are designed to enable the auditor to achieve the objectives specified in the Australian Auditing Standards, and thereby the overall objectives of the auditor. The auditor's opinion on the financial report does not cover the other information; nor does this Auditing Standard require the auditor to obtain audit evidence beyond that required to form an opinion on the financial report.

Paragraph 3 (p. 7): This Auditing Standard requires the auditor to read and consider the other information because other information that is materially inconsistent with the financial report or the auditor's knowledge obtained in the audit can indicate that there is a material misstatement of the financial report or that a material misstatement of the other information exists, either of which can undermine the credibility of the financial report and the auditor's report thereon. Such material misstatements can also inappropriately influence the economic decisions of the users for whom the auditor's report is prepared.

Moreover, unlike accrual-based earnings management and real activity earnings management, bottom-line net income is unaffected by using aggressive non-statutory earnings disclosure (Fan et al., 2010). Studies have found that when firms have limited opportunities to engage in accruals and/or real activity earnings management, they are more likely to aggressively disclose pro forma earnings (Black et al., 2014; Doyle et al., 2013; Elshafie et al., 2010). 
A few recent studies have examined underlying earnings disclosure in Australia. For example, Sek and Taylor (2011) described how Australian banks report various measures of underlying earnings over time. Cameron et al. (2012) demonstrated the underlying earnings of the top 50 ASX-listed non-mining companies between 2007 and 2009. However, no studies have examined whether equity overvaluation serves as an incentive for managers to alternate accrual-based earnings management and aggressive underlying earnings disclosure. Furthermore, none have investigated the effect of ASIC's 2011 underlying earnings disclosure guidelines on managers' use of aggressive underlying earnings disclosure to sustain the overvaluation, or how firms' corporate governance and ASIC underlying earnings disclosure guidelines affect the decision-making of managers to use earnings management mechanisms to sustain the equity overvaluation.

\subsection{Agency theory of overvalued equity and earnings management}

Several studies have examined earnings management behaviours based on the agency theory of overvalued equity. Using a sample of US data from 1964 to 2003, Chi and Gupta (2009) were the first to investigate the association between equity overvaluation and accruals management and to examine how overvaluation-induced earnings management affects a firm's future performance. The authors found that equity overvaluation intensifies accruals management, which confirms Jensen's (2005) conjecture that equity overvaluation encourages managers to manage earnings. Houmes and Skantz (2010) demonstrated that overvalued equity is an incentive for a manager's share option compensation, regardless of other reasons for overvaluation. Habib et al. (2013) examined the relationship between overvalued equity firms and audit fees in the US context. Their results show that auditors charge higher audit fees from clients that use aggressive earnings management because these firms have an incentive to overvalue equity. Marciukaityte and Varma (2008) examined the agency costs of overvaluating equity in earnings management by investigating a sample of 526 earnings management firms between 1990 and 2001. Their study found that considerable overvaluation of equity pushes managers to manage earnings, but when investors notice earnings restatements, managers correct the misstated overvaluation, which results in a loss of confidence in the managers. 
Extending Marciukaityte and Varma (2008), Baderstcher (2011) focussed on the degree and duration of overvaluation on the 'evolution' of earnings management, from accruals management to manipulating real activities, to non-GAAP earnings management. The study found that managers engage in accrual-based earnings management at the early stage of overvaluation, then resort to real activity earnings management to sustain their overvaluation. At the later stage of overvaluation, managers are more likely to engage in non-GAAP earnings management. These results suggest that equity overvaluation plays a significant role in managers choosing alternative earnings management mechanisms during the duration of equity overvaluation. Coulton et al. (2014) examined the extent to which overvalued equity motivates firms to beat earnings benchmarks and whether beating the benchmark can be interpreted as income-increasing earnings management. The authors provided evidence that overvaluation-related incentives encourage earnings management and that overvalued benchmark beaters have higher levels of abnormal accruals than do other firms that beat benchmarks.

\section{Development of hypotheses}

Jensen (2005) proposed that the agency costs of overvalued equity stem from managers who cannot (except through pure luck) produce earnings performance to maintain an overvalued stock price without participating in earnings management techniques. Managers manage earnings to avoid reporting a firm's true value as lower than expected earnings and thus be severely punished by the market (Skinner and Sloan, 2002). According to the agency theory of overvalued equity, managers of overvalued firms not only reject market correction of overvalued stock prices but also tend to sustain overvaluation by engaging in earnings management that increases reported earnings because overvaluation is an instant step towards increasing managers' welfare via incentives such as the bonuses and stock options that are usually connected with firm performance (Badertscher, 2011). The underlying assumption of this study, which builds on Jensen's (2005) agency theory of overvalued equity, is that equity overvaluation can lead to earnings management, and managers are likely to use different earnings management mechanisms during the duration of equity overvaluation. 
There are many earnings management choices that managers can use to disguise true economic performance and sustain equity overvaluation. The flexibility of accounting reporting policy provides opportunities for managers to engage in earnings management that makes the firm appear less risky or more profitable than it actually is (Fields et al., 2001; Graham et al., 2005). In choosing the type of earnings management to utilise, managers must consider the expected costs and benefits of alternative earnings management mechanisms. Each accounting choice has its costs and benefits, but the net incentives (benefits minus costs) will ultimately determine management's choice of alternative earnings management mechanisms (Desai et al., 2006; Palmrose et al., 2004).

Accrual-based earnings management is a popular choice because it has no first-order effect on cash flows and can be completed at the end of a period once the amount of pre-accrual management earnings is known (Badertscher, 2011; Doukakis, 2014; Gunny, 2010). However, accrual-based earnings management has limitations. First, aggressive choices about accruals are at a higher risk of regulatory litigation and scrutiny because accrual accounting choices are subject to auditor scrutiny, and high levels of accrual manipulation tend to be detected by regulators (Graham et al., 2005), particularly for publicly listed firms. Second, the reversing nature of accrual-based earnings management can be problematic because a firm can reverse the previous year's accrual-based earnings management to influence the current year's earnings (Badertscher, 2011). The reversing nature of accruals can limit the flexibility in applying accrual-based earnings management. Some studies argue that firms that used accrual-based earnings management extensively in previous periods tend to use other earnings management techniques in the current period, particularly if they have a continued motivation to manage earnings (Alhadab et al., 2015; Gunny, 2010).

From a valuation perspective, if the probability of detecting an earnings management technique as material misstatements is low, it is less costly than other earnings management techniques (Badertscher et al., 2012). Aggressive underlying earnings disclosure enables management to manage earnings by large amounts without reversing them, thus enabling management to achieve specific benchmarks and sustain overvalued equity (Badertscher, 2011; Black et al., 2014). However, aggressive underlying earnings disclosure is not without costs. Studies find that 
aggressive non-statutory earnings reporting is an egregious form of earnings management because share prices decline severely when investors detect opportunistic non-statutory earnings reporting, decreasing managers' reputations (Desai et al., 2006; Graham et al., 2005; Mizik and Jacobson, 2007; Palmrose et al., 2004).

Along with the agency theory of overvalued equity conjecture, this paper posits that the duration of overvaluation affects managers' decisions to use earnings management mechanisms. Specifically, in the early stage of overvaluation, managers are more likely to use accrual-based earnings management. Because accrual-based earnings management has limitations, this paper argues that the longer the duration of a firm's equity overvaluation, the greater is the manager's incentive to disclose underlying earnings in an aggressive manner to sustain the overvalued equity. Therefore, the following hypothesis is presented:

H1: The longer firms are overvalued, the more likely managers will disclose underlying earnings aggressively.

The form of corporate governance that can reduce accrual-based earnings management is not a new topic. Recent studies have focussed on examining whether corporate governance has a moderating effect on the quality of non-GAAP reporting. For example, Frankel et al. (2011) were the first to examine the relationship between non-GAAP earnings and the percentage of independent directors on the board. Their findings show that firms with a high percentage of independent directors on the board exclude items from non-GAAP earnings, suggesting that companies with higher corporate governance are more likely to report non-GAAP earnings efficiently. However, their study does not provide direct evidence on whether firms with weak corporate governance report non-GAAP earnings to mislead investors. Jennings and Marques (2011) extend Frankel et al. (2011) by using two attributes of corporate governance: percentage of shares held by institutions and percentage of independent directors on the board. They provide strong evidence that corporate governance can prevent investors from being misled by non-GAAP adjustments and earnings disclosed in quarterly earnings announcement press releases. Entwistle et al. (2012) examine whether firms with stronger credibility attributes (i.e., high corporate governance, higher quality auditors, and higher historical information quality) are 
perceived as providing more-credible non-GAAP exclusions than are firms with weaker credibility attributes. These authors find that investors view better-governed firms, firms audited by high-quality auditors, and higher historical information quality firms as providing more-credible non-GAAP exclusions, and investors price the nonGAAP reporting firms with strong credibility attributes higher than those with poor credibility attributes. Isidro and Marques (2014) find that a high-quality board can restrain opportunistic management with non-GAAP earnings reporting behaviour, particularly by reducing the opportunistic emphasis given to non-GAAP earnings reporting in press releases.

The above studies provide evidence that corporate governance plays an important role in monitoring and reducing management's earnings management behaviour. Our study attempts to examine whether corporate governance influences the decisionmaking of managers to choose earnings management mechanisms to sustain equity overvaluation. Because this study is the first in Australia to investigate the influence of corporate governance on managers' use of different earnings management mechanisms, hypothesis 2 is stated in null form below:

H2: Corporate governance does not influence managers' choice to use earnings management mechanisms.

Studies conducted in countries in which compliance with non-GAAP earnings reporting is compulsory (e.g., the US), have found that the compulsory introduction of non-GAAP guidelines can significantly increase the quality of non-GAAP earnings reported. Opportunistic non-GAAP reporting is decreased (Bowen et al., 2005), and misleading reporting practices are also decreased (Entwistle et al., 2006). The probability that firms will disclose non-GAAP earnings to meet or beat forecasts declines (Heflin and Hsu, 2008), and confidence in the market increases (Marques, 2006). Unlike in the US, ${ }^{2}$ there are no compulsory regulations that govern managers'

\footnotetext{
${ }^{2}$ The Securities Exchange Commission (SEC) introduced Regulation G (Reg G), item 10(e) of Regulation S-K, and item 12 to govern non-GAAP earnings reported outside financial statements in 2003. Reg $G$ includes all of the public reporting of non-GAAP financial valuation containing conference calls, press releases, presentations to investors, and other forms of media. To establish transparency in calculating non-GAAP earnings, the regulation demands that the reporters reconcile non-GAAP earnings with GAAP earnings. Although the SEC attempts to ensure non-GAAP earnings
} 
disclosure of underlying earnings in Australian firms. The ASIC issued its Consultation Paper 150 in March 2011, proposing guidelines to minimise any adverse effect that can result from firms' underlying earnings disclosures. These guidelines state the following: (i) managers should explain the calculation of underlying earnings and why it is important to report underlying earnings; (ii) firms should not give greater prominence to underlying earnings than to IFRS information; (iii) managers should provide a reconciliation between underlying earnings and IFRS earnings; and (iv) firms should consistently report underlying earnings (ASIC, 2011a). In December 2011, ASIC published its Regulatory Guide 230: Disclosing Non-IFRS Financial Information as a guide to clarify reporting of underlying earnings, with the aim of preventing users being misled by underlying earnings reporting. ASIC's Regulatory Guide 230 states that firms can disclose underlying earnings in communications such as directors' reports, press releases, notes to financial statements, and analyst briefings, but that reporting should not mislead financial statement users by giving greater prominence to underlying earnings than IFRS earnings information. Firms can disclose underlying earnings when such reporting assists in providing a true and fair view of financial statements. Firms must also reconcile underlying earnings and IFRS earnings by showing and explaining adjustments (ASIC, 2011b). These guidelines are similar to Reg G in the US; however, it is mandatory for US firms that disclose underlying earnings to follow Reg $\mathrm{G}$, whereas it is voluntary for Australian firms that disclose underlying earnings to follow the ASIC's guidelines. This study examines the influence of the ASIC guidelines on managers' decisions to implement aggressive underlying earnings disclosure and accrual-based earnings management. The third hypothesis is presented in null form below:

H3: The ASIC underlying earnings disclosure guidelines do not influence managers' choice to use earnings management mechanisms.

reporting is useful and has not been completed in a misguided manner, it does not prohibit non-GAAP reporting (SEC, 2003). 


\section{Research design}

\subsection{Data and sample selection}

This study used a sample of ASX 200 firms from 2009 to 2016. Financial data were obtained from the DatAnalysis database. ASX 200 firms were selected as the sample frame because the ASX 200 is recognised as the primary investment benchmark in Australia. ASX 200 firms cover approximately $78 \%$ of Australian equity market capitalisation. This paper sets out to examine the post-IFRS period; therefore, 2006, 2007, and 2008 were avoided because in the three years following the adoption of IFRS, many changes were made to financial reporting processes and systems in Australian firms that were adopting IFRS standards. To collect the underlying earnings data, we searched for information about underlying earnings in the annual reports available in the Annual Reports Online database and DatAnalysis, using the keywords underlying, adjusted, normalised, earnings before, profit before, and pro forma. Following Black and Christensen (2009), we excluded EBIT and EBITDA because they are commonly reported as standard steps in the income statement. Table 1 illustrates the detailed sample selection process. The study found that 658 firm-year observations out of 927 firm-year observations in the sample disclosed underlying earnings, and that 491 firm-year observations out of 927 firm-year observations in the sample disclosed underlying earnings figures greater than statutory earnings figures over eight observation years.

$<$ Insert Table 1 about here $>$

\subsection{Measurement of accrual-based earnings management}

\subsubsection{Accruals quality}

The quality of accruals is very important in determining the reliability of earnings information for users because high-quality earnings map more closely into cash flows (Harris et al., 2000). Dechow and Dichev (2002) viewed the accruals matching function to cash flows as very important because accruals expect future cash collections/payments and reverse them when cash previously recognised in accruals is received/paid. Thus, Dechow and Dichev (2002) proposed and tested the quality of accruals based on the observation that the total current working capital accrual-based 
earnings maps into operating cash flows in the previous period, the current period, and the next period. The unexplained portion of the variation in working capital accruals is an inverse measure of accruals quality (a larger unexplained portion indicates poorer quality), and the wider variation in the unexplained portion in working capital accruals indicates low-quality accruals (Francis et al., 2005).

The measure of accruals quality used in this paper is based on Dechow and Dichev's (2002) measure, in which the unexplained portion of the variation in working capital accruals is measured as the standard deviation in the residuals using a five-year rolling window that ends in 2012 for firm $j$, year $t$ in the following multivariate equation (1):

$T C A_{\mathrm{j}, \mathrm{t}}=\alpha_{0}+\alpha_{1} C F O_{\mathrm{j}, \mathrm{t}-1}+\alpha_{2} C F O_{\mathrm{j}, \mathrm{t}}+\alpha_{3} C F O_{\mathrm{j}, \mathrm{t}+1}+\mathrm{v}_{\mathrm{j}, \mathrm{t}}(1)$

where $\mathrm{j}$ is firm-year observation; $\mathrm{t}$ is time period from 2005 to $2012 ; T C A_{\mathrm{j}, \mathrm{t}}$ is firm $\mathrm{j}$ 's current accruals in year $\mathrm{t},=\left(\Delta C A_{\mathrm{j}, \mathrm{t}}-\Delta C L_{\mathrm{j}, \mathrm{t}}-\Delta \operatorname{Cash}_{\mathrm{j}, \mathrm{t}}+\Delta S T D_{\mathrm{j}, \mathrm{t}}\right)$, scaled by the total assets at the beginning of year $\mathrm{t} ; C F O_{\mathrm{j}, \mathrm{t}}$ is cash flow from operations in year $\mathrm{t}$, calculated as earnings before tax $\left(E_{\mathrm{j}, \mathrm{t}}\right)$ less total accruals $\left(T A_{\mathrm{j}, \mathrm{t}}\right){ }^{3}$ scaled by the total assets at the beginning of year $\mathrm{t}$; and $\mathrm{v}_{\mathrm{j}, \mathrm{t}}$ is residuals from Equation (1) representing accrual quality $\left(A Q_{\mathrm{j}, \mathrm{t}}\right)$.

\subsubsection{Innate factors of firms and discretional accrual-based earnings management}

Accruals quality is jointly determined by the relevance of underlying financial performance and by the ability of the accounting system to measure performance (Dechow et al., 2010). Therefore, accruals quality is affected by two factors: accruals that reflect the innate features of firms and those that reflect discretionary sources. Innate features are derived from business models and the operating risk and operating environments. Previous studies have shown that innate factors account for approximately $50 \%$ of variations in the accrual quality metric (Francis et al., 2005, 2008). Discretionary sources stem from the process of financial reporting and include

\footnotetext{
${ }^{3} T A_{\mathrm{j}, \mathrm{t}}=\Delta C A_{\mathrm{j}, \mathrm{t}}-\Delta C L_{\mathrm{j}, \mathrm{t}}-\Delta C a s h_{\mathrm{j}, \mathrm{t}}+\Delta S T D_{\mathrm{j}, \mathrm{t}}-D E P N_{\mathrm{j}, \mathrm{t}}, \Delta C A_{\mathrm{j}, \mathrm{t}}=$ firm $\mathrm{j}$ 's change in current assets between year t-1 and t, scaled by total assets at the beginning of year $\mathrm{t} ; \Delta C L_{\mathrm{j}, \mathrm{t}}=$ firm j's change in current liabilities between year $\mathrm{t}-1$ and $\mathrm{t}$, scaled by total assets at the beginning of year $\mathrm{t} ; \Delta \operatorname{Cash}_{\mathrm{j}, \mathrm{t}}=$ firm $\mathrm{j}$ 's change in cash between year $\mathrm{t}-1$ and $\mathrm{t}$, scaled by total assets at the beginning of year $\mathrm{t} ; \Delta S T D_{\mathrm{j}, \mathrm{t}}=$ firm $\mathrm{j}$ 's change in debt in current liabilities between year $\mathrm{t}-1$ and $\mathrm{t}$, scaled by total assets at the beginning of year $\mathrm{t}$; and $D E P N_{\mathrm{j}, \mathrm{t}}=$ firm j's depreciation and amortisation expenses in year $\mathrm{t}$, scaled by total assets at the beginning of year $\mathrm{t}$.
} 
the managerial financial reporting implementation decisions, judgements and estimates, monitoring and governance, and regulatory scrutiny (Dechow et al., 2010; Francis et al., 2005, 2008).

To separate the innate and discretionary accrual components from accrual quality, (i) company size, (ii) standard deviation of cash flow from operations, (iii) standard deviation of sales, (iv) length log operating cycle, (v) the incidence of earnings losses, and (vi) earnings variability are selected as innate factors. ${ }^{4}$ Those six innate factors are regressed on accruals quality $\left(A Q_{\mathrm{j}, \mathrm{t}}\right)$ as follows:

$A Q_{\mathrm{j}, \mathrm{t}}=\mathrm{a}_{0}+\mathrm{a}_{1} S_{i z e_{\mathrm{j}, \mathrm{t}}}+\mathrm{a}_{2}$ Opcycle $_{\mathrm{j}, \mathrm{t}}+\mathrm{a}_{3} N e g \operatorname{Earn}_{\mathrm{j}, \mathrm{t}}+\mathrm{a}_{4} C f o_{\mathrm{j}, \mathrm{t}}+\mathrm{a}_{5} S_{\text {Sales }} \mathrm{j}_{\mathrm{t}}+\mathrm{a}_{5} S D E_{\mathrm{j}, \mathrm{t}}+\mathrm{e}_{\mathrm{j}, \mathrm{t}}$

where $\mathrm{j}$ is firm-year observation, $\mathrm{t}$ is time period from 2009 to 2016; $A Q_{\mathrm{j}, \mathrm{t}}$ is the standard deviation of residuals from Equation (1) for firm $\mathrm{j}$, year $\mathrm{t}-\mathrm{v}_{\mathrm{j}, \mathrm{t}} ;$ Size $_{\mathrm{j}, \mathrm{t}}$ is natural logarithm of the total assets for firm $\mathrm{j}$, year $\mathrm{t}$; Opcycle $\mathrm{j}_{\mathrm{j}, \mathrm{t}}$ is natural logarithm of days of accounts receivable plus days of inventory for firm $\mathrm{j}$, year $\mathrm{t} ; C f o_{\mathrm{j}, \mathrm{t}}$ is standard deviation of cash flows from operations scaled by beginning total assets, computed using a five-year rolling window until 2016 for firm j, year t; Sales $\mathrm{j}_{\mathrm{j}, \mathrm{t}}$ is standard deviation of sales revenue scaled by beginning total assets, computed using a fiveyear rolling window until 2016 for firm j, year t; and $N e g E a r n_{\mathrm{j}, \mathrm{t}}$ is firm's proportion of losses over the previous five years for firm j, year t. $S D E_{\mathrm{j}, \mathrm{t}}$ is measured by the standard deviation of earnings before tax using a five-year rolling window until 2016 for firm $\mathrm{j}$, year $\mathrm{t}$.

Consistent with Francis et al. (2005), Equation (2) is measured by cross-section by industry for each year. Because the cross-sectional models require at least 10 firms in one industry (Aldamen and Duncan, 2013), this study combined the three smallest industry groups into one, giving a total of six industries for each year. The industry type is based on the Global Industry Classification Standard industry sector. Eight industries were included in the sample: energy, materials, industrials, consumer discretionary, healthcare, software, telecommunication services, and utilities. The

\footnotetext{
${ }^{4}$ Following Francis et al. (2005), this paper includes company size, standard deviation of cash flow from operations, standard deviation of sales, length logarithm operating cycle and incidence of earnings losses affecting accruals quality as firms' innate factors. Previous studies have found that earnings variability is highly related to accruals quality and suggests greater variability in earnings and lower accruals quality (Dechow and Dichev, 2002; Francis et al., 2004, 2005). Therefore, earnings variability is included as an innate factor affecting accruals quality.
} 
telecommunication services (six firms) and the utilities (six firms) were combined into one group. Because it is a high-tech industry (three firms), software was included in the healthcare category to measure cross-sectional Equation (2). ${ }^{5}$ This paper examines the influence of income-increasing accrual-based earnings management on equity overvaluation and expects that when managers are less likely to use incomeincreasing accrual-based earnings management, they tend to use income-increasing underlying exclusions to overvalue firms' equity. Thus, following previous studies (Baber et al., 2011; Laksmana and Yang, 2014), this paper measures the incomeincreasing accrual-based earnings management $\left(\operatorname{In} A M_{\mathrm{j}, \mathrm{t}}\right)$ by a dummy variable such that the positive residuals of Equation (2)- $\mathrm{e}_{\mathrm{j}, \mathrm{t}}$ are coded as ' 1 ', and ' 0 ' otherwise. The predicted values from Equation (2) are the estimated accruals' innate factors of firms.

\subsection{Measurement of overvaluation}

Following Habib et al. (2013), this paper measures the value of equity using positive lagged $\mathrm{P} / \mathrm{E}$ ratios and positive lagged $\mathrm{P} / \mathrm{B}$ ratios as proxy for equity overvaluation. ${ }^{6}$ The $\mathrm{P} / \mathrm{E}$ ratio was traditionally used to value companies because $\mathrm{P} / \mathrm{E}$ valuation is a substitute for the well-established discounted earnings model. However, the applicability of $\mathrm{P} / \mathrm{E}$ ratios in valuation has been challenged by both practitioners and academics (How and Howe, 2001; Kim and Ritter, 1999). Because transitory earnings account for a large part of profits and an increasing number of firms engage in earnings management, the usefulness of earnings in valuation declines (Collins et al., 1997, 1999) due to issues connected with $\mathrm{P} / \mathrm{E}$ ratios, in which $\mathrm{P} / \mathrm{B}$ ratios have become an increasingly important valuation price-multiple. Studies have shown that when the equity's book value is compared with dividends and earnings, the equity book value had the highest explanatory power of empirical models (Collins et al., 1997, 1999). However, because different firms identify various numbers of intangible assets on their books, the price-multiple calculated using the book value of equity might not be

\footnotetext{
${ }^{5}$ This paper follows Aldamen and Duncan's (2013) measurement of industry type. In that study, telecommunication services and utilities were combined into one industry group to measure the crosssectional model.

${ }^{6}$ Empirical evidence shows that equity overvaluation is positively related to the subsequent incomeincreasing earnings management (Chi and Gupta, 2009), and highly valued firms tend to use discretionary accruals to manage earnings upwards in the year following the overpricing (Houmes and Skantz, 2010). This study, following Habib et al. (2013), uses lagged measurements. This paper also trimmed the top and the bottom one per cent of the sample.
} 
applied to firms with different proportions of unrecognised intangible assets (How et al., 2007, p. 106). Because the $\mathrm{P} / \mathrm{E}$ ratios and $\mathrm{P} / \mathrm{B}$ ratios have limitations, the valuation of equity is measured by the average of lagged $\mathrm{P} / \mathrm{E}$ ratios and lagged $\mathrm{P} / \mathrm{B}$ ratios in this paper. ${ }^{7}$ Using aggregative measurement by averaging the two is appropriate because lagged $\mathrm{P} / \mathrm{E}$ ratios and lagged $\mathrm{P} / \mathrm{B}$ ratios present one factor (see Table 3, Panel B factor analysis). This research design is framed to be consistent with Jensen's (2005) view that equity overvaluation drives managers to manipulate earnings (see Appendix for variables' proxy and measurement).

To identify equity-overvalued firms, firms are ranked based on the $P E P B_{\mathrm{j}, \mathrm{t}}$ ratio for each year, where those firms in the highest quartile $\operatorname{rank}^{8}$ of $P E P B_{\mathrm{j}, \mathrm{t}}$ indicate equity overvaluation. To capture the notion of sustained equity overvaluation or duration of equity overvaluation, this paper identifies firms that have been in the top quartile of $P E P B_{\mathrm{j}, \mathrm{t}}$ for $1\left(\right.$ Over $\left._{\mathrm{j}, \mathrm{t}, \mathrm{t}}\right), 2\left(\right.$ Over $\left._{\mathrm{j} \mathrm{j}, \mathrm{t}}\right), 3\left(\right.$ Over $\left._{\mathrm{j} \mathrm{j}, \mathrm{t}}\right), 4\left(\right.$ Over $\left._{\mathrm{j}, \mathrm{t}}\right), 5$ or more than $5\left(\right.$ Over $\left._{\mathrm{j}, \mathrm{t}}\right)$ consecutive years.

\subsection{Duration of equity overvaluation and earnings management (H1)}

The models for testing $\mathrm{H} 1$ were designed as follows:

EM $\mathrm{j}_{\mathrm{j}, \mathrm{t}}=\mathrm{a}_{0}+\sum \mathrm{b}_{0-5}$ Over $_{(\mathrm{i}) \mathrm{j}, \mathrm{t}}+\mathrm{c}_{1}$ Controls $_{\mathrm{j}, \mathrm{t}}+\mathrm{c}_{2}$ Year effects $+\mathrm{c}_{3}$ Industry effects $+\mathrm{e}_{\mathrm{j}, \mathrm{t}}(3)$

where $\mathrm{j}$ is firm-year observation, $\mathrm{t}$ is time period from 2009 to 2016.

Dependent variables: $E M_{\mathrm{j}, \mathrm{t}}$ is either $\operatorname{In} E x_{\mathrm{j}, \mathrm{t}}$ or $\operatorname{In} A M_{\mathrm{j}, \mathrm{t}} \operatorname{In} E x_{\mathrm{j}, \mathrm{t}}$ is aggressive underlying earnings disclosure measured by a dummy variable that equals 1 if $\mathrm{j}$ firm discloses an underlying earnings number that is greater than the statutory earnings in year $t$, and 0 otherwise. $\operatorname{In} A M_{\mathrm{j}, \mathrm{t}}$ is income-increasing accrual-based earnings management that equals 1 if residuals $\left(\mathrm{e}_{\mathrm{j}, \mathrm{t}}\right)$ of Equation (2) is positive, or 0 otherwise.

Independent variables: $O v e r_{(\mathrm{i}) \mathrm{j}, \mathrm{t}}$ is a dummy variable equal to 1 if $\mathrm{j}$ firm has been in the top quartile of $P E P B_{\mathrm{j}, \mathrm{t}}$ for (i) consecutive years, and 0 otherwise. Specifically, Over $_{\mathrm{j}, \mathrm{t}}$ equals 1 if $\mathrm{j}$ firm was overvalued for one year during the sample years, and 0

\footnotetext{
${ }^{7} \mathrm{P} / \mathrm{E}$ ratios and $\mathrm{P} / \mathrm{B}$ ratios have been ranked as high and low; the PEPB is the average of the rankings.

${ }^{8}$ Unlike Badertscher (2011), this paper uses quartile value rather than quintile value due to the small sample size. Therefore, following Habib et al. (2013), this paper measures overvalued equity using quartile values.
} 
otherwise. Over $2 \mathrm{j}, \mathrm{t}$ equals 1 if $\mathrm{j}$ firm was overvalued for two consecutive years during the sample years, and 0 otherwise. Over $_{3 \mathrm{j}, \mathrm{t}}$ equals 1 if $\mathrm{j}$ firm was overvalued for three consecutive years during the sample years, and 0 otherwise. Over $_{4 \mathrm{j}, \mathrm{t}}$ equals 1 if $\mathrm{j}$ firm was overvalued for four consecutive years during the sample years, and 0 otherwise. Over $_{5 \mathrm{j}, \mathrm{t}}$ equals 1 if $\mathrm{j}$ firm was overvalued for five or more than five consecutive years during the sample years, and 0 otherwise.

Control variables: Following the literature, this paper includes several control variables that influence the likelihood of firm equity overvaluation and earnings management.

Accruals-specific controls: Following previous studies (Badertscher, 2011; Black et al., 2014; Cohen and Zarowin, 2010), this paper includes an indicator variable Litigation $_{\mathrm{j}, \mathrm{t}}$ that equals 1 if $\mathrm{j}$ firm is in a high litigation risk industry to capture the litigation penalties. ${ }^{9}$ This paper includes Litigation $_{\mathrm{j}, \mathrm{t}}$ as a specific control variable because accrual-based earnings management is more likely than aggressive underlying earnings disclosure to be detected and punished; thus, greater perceived litigation penalties should decrease the tendency for accrual-based earnings management.

Another specific control variable for accruals widely recorded in the accounting literature is Big4 auditors. Following previous studies (Badertscher, 2011; Black et al., 2014; Doukakis, 2014), this paper includes Big4 $4_{\mathrm{j}, \mathrm{t}}$ as a specific control variable that is measured by a dummy variable that equals 1 if $\mathrm{j}$ firm's auditor is a Big 4 audit company, and 0 otherwise. This variable is included because previous studies suggest that auditors play a monitoring role, and the presence of a Big 4 auditor restricts accrual-based earnings management practices (Francis and Wang, 2008). It is expected that increased scrutiny enhances the probability of discovering accrual-based earnings management, but such scrutiny should not affect a manager's decision to aggressively disclose underlying earnings because it typically falls outside an auditor's responsibility.

\footnotetext{
${ }^{9}$ Following Barton and Simko (2002) and Cohen and Zarowin (2010), high-litigation industries are pharmaceuticals/biotechnology, software, and service industries. Pharmaceuticals/biotechnology is a sub-group of the healthcare sector.
} 
Underlying earnings-specific controls: Previous research indicates that meeting earnings targets and avoiding current statutory losses is a useful means of explaining pro forma earnings disclosures. These studies suggest that managers have strong incentives to manipulate non-statutory earnings when firms miss their earnings targets or experience current statutory earnings losses (Barth et al., 2012; Black and Christensen, 2009; Doyle et al., 2013; Elshafie et al., 2010; Hitz, 2010; Isidro and Marques, 2014). This paper includes the dummy variable $\operatorname{Loss}_{\mathrm{j}, \mathrm{t}}$, which equals 1 if $\mathrm{j}$ firm experiences a current statutory earnings loss in year $t$, and 0 otherwise, whereas the dummy variable Meet $_{\mathrm{j}, \mathrm{t}}$ equals 1 if $\mathrm{j}$ firm's current statutory earnings are greater than or equal to previous statutory earnings, and 0 otherwise.

General control variables include Leverage $_{\mathrm{j}, \mathrm{t}}$ (DeFond and Jiambalvo, 1994; Doukakis, 2014; Francis and Wang, 2008); firm growth measured by market-to-book ratio $\left(M t o B_{\mathrm{j}, \mathrm{t}}\right)$ and sales growth $\left(\operatorname{Sales} G_{\mathrm{j}, \mathrm{t}}\right)$ (Black et al., 2014; Doyle et al., 2013; Lougee and Marquardt, 2004; Zang, 2012); firm profitability, measured by return of equity $\left(R O E_{\mathrm{j}, \mathrm{t}}\right)$ (Doukakis, 2014; Doyle et al., 2007, 2013; Frankel et al., 2011); and capital intensity $\left(\right.$ Capital $_{\mathrm{j}, \mathrm{t}}$ ) (Baginski et al., 1999; Francis et al., 2004). This study also includes net operating assets at the beginning of the year as a control variable, because previous net operating assets - which indicate the balance sheet constraints affect current managers' decisions to use earnings management (Badertscher, 2011). Net operating assets at the beginning of a year $\left(\mathrm{NOA}_{\mathrm{j}, \mathrm{t}}\right)$ are measured by shareholders' equity minus cash, cash equivalent, plus total debt, divided by lagged sales for firm $\mathrm{j}$, at the beginning of year t. Firm size $\left(M_{k t c a p}, \mathrm{j}\right)$ is measured by the natural logarithm of market capitalisation at the beginning of year t (Doukakis, 2014; Ettredge et al., 2005; Lundholm and Myers, 2002). This paper includes the year and industry effects to control the unobservable confounding variables that differ from time to time, but are constant across industries, and the unobservable confounding variables that differ across industries, but are constant over time. Corporate governance is measured by the percentage of independent directors on the board $\left(I N D_{j, t}\right)$ in relation to the total number of directors on the board. We obtained corporate governance data from the corporate governance section of the annual report of each firm.

This study includes underlying earnings disclosure or accrual-based earnings management because control variables in previous studies indicated that accrual- 
based earnings management and non-statutory earnings disclosures are substitute mechanisms of earnings management (Black et al., 2014; Cohen et al., 2008; Doukakis, 2014; Doyle et al., 2013; Elshafie et al., 2010). If the dependent variable is accrual-based earnings management $\left(\operatorname{In} A M_{\mathrm{j}, \mathrm{t}}\right)$, then it controls for aggressive underlying earnings disclosures $\left(\operatorname{InEx} x_{\mathrm{j}, \mathrm{t}}\right)$; the converse also applies.

To examine the influence of corporate governance in $\mathrm{H} 2$, we divided our sample into two sub-samples: firms with high corporate governance versus firms with low corporate governance. Each year is ranked on $I N D_{\mathrm{j}, t}$, and the upper quartile of $I N D_{\mathrm{j}, \mathrm{t}}$ is selected as a proxy of high corporate governance, whereas the lower quartile of $I N D_{\mathrm{j}, \mathrm{t}}$ is selected as a proxy of low corporate governance.

To examine $\mathrm{H} 3$ - that is, whether ASIC underlying earnings guidelines in 2011 would affect managers' decision-making in using different earnings management techniques to sustain equity overvaluation - we examined the post-ASIC underlying earnings guidelines period (2013-2016) ${ }^{10}$ and restricted our sample to the firms that disclosed underlying earnings. Because the guidelines are voluntarily followed by firms, we divided our sample into two sub-samples: firms that voluntarily conform to the guidelines and firms that do not voluntarily conform to the guidelines to disclose underlying earnings. If a firm conforms to all of ASIC's guidelines - (i) firms explain the calculation of underlying earnings and why it is important to report them; (ii) firms do not provide greater prominence to underlying earnings than to IFRS earnings; (iii) firms provide a reconciliation between underlying earnings and IFRS earnings; and (iv) firms consistently report underlying earnings (ASIC, 2011a, 2011b) - over the four reporting periods from 2013 to 2016, then the study considers the firm compliant.

\section{Analysis and results}

\subsection{Descriptive statistics}

Table 2 documents the descriptive statistics of the variables for earnings management and equity overvaluation variables and shows the differences between the top and bottom quartiles. For the earnings management mechanisms (InAM $M_{\mathrm{j}, \mathrm{t}}$ : income-

\footnotetext{
${ }^{10}$ We avoid 2011 and 2012 because we want to leave time for firms to familiarise themselves with the guidelines.
} 
increasing accrual-based earnings management, and $\operatorname{In} E x_{\mathrm{j}, \mathrm{t}}$ : aggressive underlying earnings disclosure), the median of $\operatorname{In} A M_{\mathrm{j}, \mathrm{t}}(0.000)$ is lower than the median of $\operatorname{In} E x_{\mathrm{j}, \mathrm{t}}$ (1.000), which means that sample firms are more likely to disclose underlying earnings aggressively. Examining the overvaluation variables, the mean and median of $P E_{\mathrm{j}, \mathrm{t}}$ (15.274 and 14.190, respectively) are higher than the mean and median of $P B_{\mathrm{j}, \mathrm{t}}$ (2.607 and 1.830, respectively). The mean (median) of $P B P E_{\mathrm{j}, \mathrm{t}}$ is $8.940(8.190)$, with an interquartile range of (5.870) to (11.285).

\section{$<$ Insert Table 2 about here $>$}

\subsection{Pearson and Spearman correlations and factor analysis}

Table 3, Panel A shows the Pearson and Spearman correlations of key variables. $I n E x_{\mathrm{j}, \mathrm{t}}$ is significantly negatively correlated with $\operatorname{In} A M_{\mathrm{j}, \mathrm{t}}$ under Spearman correlation (correlation $=-0.002, p$-value $=0.046)$ and Pearson correlation $($ correlation $=-0.043$, p-value $=0.040)$. These results confirm those of previous studies (Black et al., 2014; Doyle et al., 2013; Elshafie et al., 2010), in which accrual-based earnings management and aggressive underlying earnings disclosures are substitute earnings management mechanisms. Moving on to the correlations between earnings management mechanisms and overvaluation measurements, $I n A M_{\mathrm{j}, \mathrm{t}}$ is significantly positively correlated to $O v e r_{1 \mathrm{j}, \mathrm{t}}$ and $O v e r_{2 \mathrm{j}, \mathrm{t}}$ under both the Pearson and Spearman correlation tests. InEx $x_{\mathrm{j}, \mathrm{t}}$ is significantly positively correlated to $O v e r_{3 \mathrm{j}, \mathrm{t}}$, Over ${ }_{\mathrm{j} \mathrm{j}, \mathrm{t}}$, and Over $_{5 \mathrm{j}, \mathrm{t}}$ under Pearson and Spearman correlations. Table 3, Panel B presents the factor analysis for measuring overvaluation and indicates that the PE and PB ratios represent one factor. Therefore, this paper appropriately combines the two measurement ratios into one variable to represent a firm's valuation measurement.

$<$ Insert Table 3 about here $>$

\subsection{Regression results}

5.3.1. Results for duration of overvaluation and earnings management mechanisms (H1)

Table 4 shows the results of $\mathrm{H} 1$ using the time-industry fixed-effects logit regression model. The first and second models are tested with dependent $\operatorname{In} A M_{\mathrm{j}, \mathrm{t}}$ and $\operatorname{In} E x_{\mathrm{j}, \mathrm{t}}$, 
respectively. The results of the first model show that $I n A M_{\mathrm{j}, \mathrm{t}}$ is significantly positively related to Over $_{1 \mathrm{j}, \mathrm{t}}($ coefficient $=0.571, \mathrm{p}$-value $=0.025)$ and to $\operatorname{Over}_{2 \mathrm{j}, \mathrm{t}}($ coefficient $=$ $1.507, \mathrm{p}$-value $=0.065)$, whereas Over $_{3 \mathrm{j}, \mathrm{t}}$ Over $_{4 \mathrm{j}, \mathrm{t}}$, and Over $_{5 \mathrm{j}, \mathrm{t}}$ are not significantly associated with $I n A M_{\mathrm{j}, \mathrm{t}}$. The results of the first model suggest that in the early stage of overvaluation, firms are more likely to engage in income-increasing accrual-based earnings management. In the later stage of overvaluation, managers are less likely to use income-increasing accrual-based earnings management, which could be explained by the reversing nature of accrual-based earnings management, in which managers' ability to use income-increasing accrual-based earnings management decreases. The second model demonstrates that $I n E x_{\mathrm{j}, \mathrm{t}}$ is significantly positively associated with Over $_{3 \mathrm{j}, \mathrm{t}}($ coefficient $=0.877, \mathrm{p}$-value $=0.007)$, Over $_{4 \mathrm{j}, \mathrm{t}}($ coefficient $=1.007, \mathrm{p}$-value $=$ 0.027 ), and Over $_{5 \mathrm{j}, \mathrm{t}}($ coefficient $=0.939, \mathrm{p}$-value $=0.002)$; thus, after a firm has been overvalued in the early stage using income-increasing earnings management, firms tend to sustain their equity overvaluation by engaging in aggressive underlying earnings disclosure to define underlying earnings as higher than statutory earnings. The results of Table 4 demonstrate that after an extended period of equity overvaluation, firms are unable to engage in further accrual-based earnings management and therefore resort to disclosing underlying earnings aggressively.

$<$ Insert Table 4 about here $>$

5.3.2. Influence of corporate governance on managers' choice to use earnings management mechanisms (H2)

Table 5 shows the time-industry fixed-effects logit regression results for H2. The first and second models show the results of firms with high corporate governance (i.e., a high proportion of independent directors), whereas the third and fourth models show the results of firms with low corporate governance (i.e., a low proportion of independent directors). The results show that for the high corporate governance firms, only Over $_{1 \mathrm{j}, \mathrm{t}}$ is very weakly significant and positively related with $\operatorname{In}_{A} M_{\mathrm{j}, \mathrm{t}}$ (coefficient $=0.866, \mathrm{p}$-value $=0.096$ ); however, Over $_{4 \mathrm{j}, \mathrm{t}}$ and Over $_{5 \mathrm{j}, \mathrm{t}}$ are significantly positively associated with $I n E x_{\mathrm{j}, \mathrm{t}}$ (coefficient $=0.057, \mathrm{p}$-value $=0.043$; coefficient $=0.232, \mathrm{p}$ value $=0.020$, respectively). In the low corporate governance firms, $\operatorname{In} A M_{\mathrm{j}, \mathrm{t}}$ is significantly positively related with $\operatorname{Over}_{\mathrm{ij}, \mathrm{t}}($ coefficient $=2.110, \mathrm{p}$-value $=0.053$ ), Over $_{\mathrm{j}, \mathrm{t}}($ coefficient $=1.572, \mathrm{p}$-value $=0.022)$, Over $_{3 \mathrm{j}, \mathrm{t}}($ coefficient $=2.493, \mathrm{p}$-value $=$ 
$0.004)$, and over $_{4 \mathrm{j}, \mathrm{t}}($ coefficient $=2.058, \mathrm{p}$-value $=0.010) ; I n E x_{\mathrm{j}, \mathrm{t}}$ is significantly positively associated with Over $_{3 \mathrm{j}, \mathrm{t}}($ coefficient $=2.176, \mathrm{p}$-value $=0.034)$, Over $_{4 \mathrm{j}, \mathrm{t}}$ (coefficient $=0.112, \mathrm{p}$-value $=0.049)$, and Over $_{5 \mathrm{j}, \mathrm{t}}($ coefficient $=0.586, \mathrm{p}$-value $=$ $0.000)$. The results suggest that corporate governance could constrain managers to apply accrual-based earnings management to sustain the early years of equity overvaluation but could not restrain managers from using aggressive underlying earnings disclosure in the later years of equity overvaluation. Specifically, the managers in high corporate governance firms sustain the later stage of equity overvaluation by aggressive underlying earnings disclosure. The managers in low corporate governance firms apply both earnings management mechanisms to sustain equity overvaluation.

$<$ Insert Table 5 about here $>$

5.3.3. Influence of ASIC underlying earnings guidelines on using earnings mechanisms (H3)

Table 6 shows the year industry fixed-effects logit regression results for H3. Because ASIC guidelines are voluntarily followed by reporting firms, we investigate two subsamples (i.e., firms that conform to ASIC guidelines and firms that do not conform to ASIC guidelines) to understand the influence of the guidelines on managers' choice of earnings management to sustain overvaluation. We focus on the post-ASIC period (i.e., 2013-2016) and limit our analysis to the observations that disclose underlying earnings to test $\mathrm{H} 3$. The first and second models present the results for the sample with the observations that conform to ASIC underlying earnings disclosure guidelines, whereas the third and fourth models show the results for the sample with the observations that do not conform to ASIC underlying earnings disclosure guidelines. The results show that for the compliant firms, only Over $_{2 \mathrm{j}, \mathrm{t}}$ is significantly positively associated with $I n E x_{\mathrm{j}, \mathrm{t}}($ coefficient $=0.897, \mathrm{p}$-value $=0.046)$; none of the other overvaluations are related to either $I n A M_{\mathrm{j}, \mathrm{t}}$ or $\operatorname{In} E x_{\mathrm{j}, \mathrm{t}}$. For the non-compliant firms, $\operatorname{In} A M_{\mathrm{j}, \mathrm{t}}$ is significantly positively related to $\operatorname{Over}_{\mathrm{j} \mathrm{j}, \mathrm{t}}($ coefficient $=4.102$, p-value $=0.050)$, Over $_{2 \mathrm{j}, \mathrm{t}}($ coefficient $=2.778, \mathrm{p}$-value $=0.003)$, and Over $_{3 \mathrm{j}, \mathrm{t}}($ coefficient $=$ $0.313, \mathrm{p}$-value $=0.061) ; I E x_{\mathrm{j}, \mathrm{t}}$ is significantly positively associated with Over $_{\mathrm{j}, \mathrm{t}}$ $($ coefficient $=1.442, \mathrm{p}$-value $=0.007)$, Over $_{3 \mathrm{j}, \mathrm{t}}($ coefficient $=2.797, \mathrm{p}$-value $=0.003)$, and Over $_{4 \mathrm{j}, \mathrm{t}}$ (coefficient $=0.983, \mathrm{p}$-value $\left.=0.056\right)$. The results suggest that firms that 
conform to the ASIC guidelines are less likely to use earnings mechanisms to sustain equity overvaluation, whereas non-compliant firms use both accrual-based earnings management and aggressive underlying earnings disclosure to sustain equity overvaluation.

$<$ Insert Table 6 about here $>$

\section{Additional tests}

\subsection{Limited ability using accrual-based earnings management}

To provide further evidence on how earnings management choices interact as the duration of overvaluation increases, this study examines a subset of firms that are likely to be constrained in their ability to manage earnings through accruals. According to Jensen (2005), the duration of overvaluation motivates managers to engage in different earnings management techniques. This paper assumes that if the firm has a limited ability to use accrual-based earnings management, the firm will more likely engage in aggressive underlying earnings disclosure. We expect that accrual-based earnings management-constrained firms are more likely to engage in aggressive underlying earnings disclosure to sustain overvaluation.

Because overvalued firms decide to manage reported earnings, this section investigates whether the constraints of using accrual-based earnings management would encourage managers to disclose underlying earnings or to disclose them in an aggressive manner. Due to the constrained flexibility of accruals, the ability of managers to manage accruals upwards in the current period is limited by accrual management activities in previous periods. This paper follows previous studies (Badertscher, 2011; Barton and Simko, 2002; Zang, 2012), in which net operating assets $\left(N O A_{\mathrm{j}, \mathrm{t}}\right)$ are used as a proxy for the extent of accruals management in previous periods to represent a firm's ability to manage earnings using accruals. If the net operating assets at the beginning of the year are high, managers' abilities to use accruals to manipulate earnings are reduced in the current year because the balance sheet and income statement are articulated. Therefore, abnormal accruals shown in past earnings can also be shown in net assets; hence, the latter are overstated when firms have practised accrual management previously (Barton and Simko, 2002; Black et al., 2014; Zang, 2012). Because the underlying earnings exclusions do not include a 
practical accounting system entry (there are no debit and credit adjustments required), aggressive underlying earnings disclosure is not necessarily constrained by the balance sheet, as accruals would be (Doyle et al., 2013).

To investigate whether firms with constraints on engaging accrual-based earnings management are more likely to disclose underlying earnings aggressively to sustain the equity overvaluation, this section focusses on a sub-sample of firms that are constrained in their ability to engage in accrual-based earnings management. This sub-sample is measured by net operating assets $\left(N O A_{\mathrm{j}, \mathrm{t}}\right)$. High values of $N O A_{\mathrm{j}, \mathrm{t}}$ represent low ability to manipulate earnings using accruals in the current year. To calculate the high values of $N O A_{\mathrm{j}, \mathrm{t}}$, each year is ranked on $N O \mathrm{~A}_{\mathrm{j}, \mathrm{t}}$, and the upper quartile of $N O A_{\mathrm{j}, \mathrm{t}}$ is selected as a proxy of accruals constraining firms.

These results (presented in Table 7) indicate that firms with limited accrual-based earnings management options do not engage in accrual-based earnings management. As the duration of overvaluation increases, they disclose underlying earnings aggressively to maintain overvaluation. Specifically, the first model finds that ${ }_{\text {ver }} r_{\mathrm{j}, \mathrm{t}}$ is significantly negatively associated with $\operatorname{In} A M_{\mathrm{j}, \mathrm{t}}$ (coefficient $=-0.205$, p-value $=$ $0.020),{ }^{11}$ and the second model finds that $I n E x_{j, t}$ is significantly positively associated with Over $_{2 \mathrm{j}, \mathrm{t}}($ coefficient $=0.515, \mathrm{p}$-value $=0.042)$, Over $_{3 \mathrm{j}, \mathrm{t}}($ coefficient $=0.790, \mathrm{p}$ value $=0.008)$, Over $_{4 \mathrm{j}, \mathrm{t}}($ coefficient $=1.855, \mathrm{p}$-value $=0.042)$, and Over $_{\mathrm{j}, \mathrm{t}, \mathrm{t}}($ coefficient $=0.807$, $\mathrm{p}$-value $=0.000$ ). The results in Table 7 suggest that if accrual-constrained firms find it difficult to apply accrual-based earnings management, they tend to disclose underlying earnings aggressively to sustain the overvaluation.

$<$ Insert Table 7 about here $>$

\footnotetext{
$11 \mathrm{We}$ have found that the coefficient of OVER on InAM (income-increasing accrual earnings management) turns negative (after Over1) when there is a high level of accrual earnings management constraints. This result differs from Badertscher's (2011) for the following two reasons: first, InAM is a dummy variable; second, there are significant variations between Australia and the US in relation to market competition, firm characteristics, economic structure, governance environment, and major industries. For example, Australia follows a principle-based balance sheet-oriented conceptual framework in accounting judgement, a common law legal system, a high level of shareholder protection, and low conformity between taxation reporting and financial accounting; in addition, there are some differences with the US in terms of regulatory and reporting environments (Chalmers et al., 2008, 2011; Lont et al., 2010).
} 


\section{Conclusion}

This study tests and extends the assumption developed by Jensen's (2005) agency theory of overvalued equity. The purposes of this paper are as follows: first, to examine whether the duration of overvaluation affects managers' choice to use accrual-based earnings management and aggressive underlying earnings disclosure; second, to investigate the influences of corporate governance on managers' choice to use different earnings management mechanisms to sustain the equity overvaluation; and third, to examine the effects of the ASIC underlying reporting guidelines on managers' choice to use different earnings management mechanisms to sustain the equity overvaluation. Jensen (2005) predicts that overvaluation leads managers to engage in alternative earnings management techniques to sustain the firm's overvalued equity. This paper provides evidence that is consistent with this reasoning, finding that overvalued firms engage in accrual-based earnings management in the early stage. As overvaluation continues, overvalued firms are more likely to disclose underlying earnings and to do so in an aggressive manner to maintain the overvaluation. Furthermore, this paper finds that in firms with low corporate governance, managers are more likely to use both earnings management techniques to sustain equity overvaluation, whereas in firms with high corporate governance, managers do not apply accrual-based earnings management, although they nevertheless disclose underlying earnings aggressively to sustain equity overvaluation. Finally, this study shows that firms that do not conform to the ASIC guidelines are more likely to sustain the overvaluation by using both earnings management techniques, whereas this behaviour is not observed in firms that conform to the ASIC guidelines. Additional tests demonstrate that when managers are constrained by using accrual-based earnings management, they will only engage in aggressive underlying earnings disclosure to sustain the overvaluation.

Two limitations should be considered when interpreting the results. First, aggressive underlying earnings disclosure is new in the earnings management literature. Due to a lack of guidance found in the literature, the control variables of underlying earnings might not have comprehensively explained underlying earnings disclosure. This paper focussed on the managers' choice to use accrual-based earnings management or aggressive underlying earnings disclosure. A future study can examine the influence 
of real activities of earnings management on aggressive underlying earnings disclosure. Second, although we use models of time-industry effects to control for the unobservable confounding variables that differ from time to time and for unobservable confounding variables that differ across industries, we could not fully control for all other unobservable variables that influence the explanatory variables.

The results of this paper provide several avenues for future research. First, because the paper only examined the relationship between overvaluation and managers' decisions to use accrual-based earnings management and underlying earnings disclosure, researchers can extend the effect of the real activity earnings management on overvaluation and managers' choices to use accrual-based earnings management, real activities earnings management, and underlying earnings disclosure. Second, future research could also examine the factors that cause firms to become overvalued and the interventions that can mitigate the agency costs of overvalued equity, such as the roles of governments, regulators, and interventions that constrain pernicious earnings management. 


\section{References}

Adams, B., Carow, K., Perry, T., 2009. Earnings management and initial public offerings: The case of the depository industry. J. of Bank. and Finance 33, 2363-2372.

Aldamen, H., Duncan, K., 2013. Pricing of innate and discretionary accruals in Australian debt. Account. and Finance 53, 31-53.

Alhadab, M., Clacher, I., Keasey, K., 2015. Real and accrual-based earnings management and IPO failure risk. Account. and Bus. Res. 45, 55-92.

Australian Institute of Company Directors (AICD) and Financial Services Institute of Australasia (FINSIA) 2009. Underlying Profit: Principles of Reporting of Non-Statutory Profit Information. AICD and FINSIA, Sydney, Australia.

Australian Securities and Investments Commission (ASIC) 2011a. Disclosing Financial Information Other Than in Accordance with Accounting Standards. ASIC, Australia.

Australian Securities and Investments Commission (ASIC) 2011b. Regulatory Guide 230: Disclosing Non-IFRS Financial Information. ASIC, Australia.

Baber, W.R., Kang, S., Li, Y., 2011. Modelling discretionary accrual reversal and the balance sheet as an earnings management constraint. The Account. Rev. 86, $1189-1212$.

Badertscher, B., 2011. Overvaluation and the choice of alternative earnings management mechanisms. The Account. Rev. 86, 1491-1518.

Badertscher, B., Collins, D., Lys, T., 2012. Discretionary accounting choices and the predictive ability of accruals with respect to future cash flows. J. of Account. and Economics 52, 330-352.

Baginski, S., Lorek, K., Willinger, G.L., Branson, B., 1999. The relationship between economic characteristics and alternative annual earnings persistence measures. The Account. Rev. 74, 105-120.

Barth, M., Gow, I., Taylor, D., 2012. Why do pro forma and street earnings not reflect changes in GAAP? Evidence from SFAS 123R. Rev. of Account. Stud. 17, 526-562.

Barton, J., Simko, P., 2002. The balance sheet as an earnings management constraint. The Account. Rev.77, 1-27. 
Bergstresser, D., Philippon, T., 2006. CEO incentives and earnings management. J. of Financial Economics 80, 511-529.

Black, D.E., Christensen, T.E., 2009. US managers' use of "pro forma” adjustments to meet strategic earnings targets. J. of Bus. Finance \& Account. 36, 297-326.

Black, E., Christensen, T., Joo, T., Schmardebeck, R., 2014. The relation between earnings management and pro forma reporting. Working Paper.

Boral Limited, 2010. Annual Report.

BHP, 2017. BHP annual report 2017. https://www.bhp.com//media/documents/investors/annual-reports/2017/bhpannualreport2017.pdf (Accessed 4 December 2018).

Bowen, R.M., Davis, A.K., Matsumoto, D.A., 2005. Emphasis on pro forma versus gaap earnings in quarterly press releases: Determinants, SEC intervention, and market reactions. The Account. Rev. 80, 1011-1038.

Brown, L.D., Caylor, M.L., 2005. A temporal analysis of quarterly earnings thresholds: Propensities and valuation consequences. The Account. Rev. 80, 423-440.

Chalmers, K., Clinch, G., Godfrey, J.M., 2008. Adoption of international financial reporting standards: Impact on the value relevance of intangible assets. Australian Account. Rev. 18, 237-247.

Chalmers, K., Clinch, G., Godfrey, J.M., 2011. Changes in value relevance of accounting information upon IFRS adoption: Evidence from Australia. Australian J. of Manag. 36, 151-173.

Chi, J., Gupta, M., 2009. Overvaluation and earnings management. J. of Bank. and Finance 33, 1652-1663.

Cohen, D.A., Dey, A., Lys, T., 2008. Real and accrual-based earnings management in the pre- and post-Sarbanes Oxley periods. The Account. Rev. 83, 757-787.

Cohen, D.A., Zarowin, P., 2010. Accrual-based and real earnings management activities around seasoned equity offerings. J. of Account. and Economics, 50, $2-19$.

Collins, D., Maydew, W., Weiss, I., 1997. Changes in the value-relevance of earnings and book value over past forty years. J. of Account. and Economics 24, 39-67.

Collins, D., Pincus, M., Xie, H., 1999. Equity valuation and negative earnings: The role of book value of equity. The Account. Rev. 74, 29-61. 
Coulton, J., Saune, N., Taylor, S.L., 2014. Overvalued equity, benchmark bearing and unexpected accruals. Working Paper, School of Business, University of New South Wales, Australia.

Dechow, P., Dichev, I., 2002. The quality of accruals and earnings: The role of accrual estimation errors. The Account. Rev. 77, 35-59.

Dechow, P., Ge, W., Schrand, C., 2010. Understanding earnings quality: A review of the proxies, their determinants and their consequences. J. of Account. and Economics 50, 344-401.

DeFond, M.L., Jiambalvo, J., 1994. Debt covenant violation and manipulation of accruals. J. of Account. and Economics 17, 145-176.

Desai, H., Hogan, C., Wilkins, M., 2006. The reputational penalty for aggressive accounting: Earnings restatements and management turnover. The Account. Rev. 81, 83-112.

Doukakis, L.C., 2014. The effect of mandatory IFRS adoption on real and accrualbased earnings management activities. J. of Account. and Public Policy 33, $551-572$.

Doyle, J., Ge, W., McVay, S., 2007. Accruals quality and internal control over financial reporting. The Account. Rev. 82, 1141-1170.

Doyle, J., Jennings, J., Soliman, M., 2013. Do managers define non-GAAP earnings to meet or beat analyst forecasts. J. of Account. and Economics 56, 40-56.

Doyle, J., Lundholm, R., Soliman, M., 2003. The predictive value of expenses excluded from non-GAAP earnings. Rev. of Account. Stud. 8, 145-174.

Efendi, J., Srivastava, A., Swanson, E., 2007. Why do corporate managers misstate financial statements? The role of in-the-money options and other incentives. J. of Financial Economics 85, 667-708.

Elshafie, E., Yen, A., Yu, M., 2010. The association between pro forma earnings and earnings management. Rev. of Account. and Finance 9, 139-155.

Entwistle, G.M., Feltham, G.D., Chima, M., 2006. Financial reporting regulation and the reporting of pro forma earnings. Account. Horizons 20, 39-55.

Entwistle, G.M., Feltham, G.D., Mbagwu, C., 2012. Credibility attributes and investor perceptions of non-GAAP earnings exclusions. Account. Perspectives 11, $229-257$.

Ernst and Young, 2007. Reported Earnings-Trends, Analysis and Predictions. Ernst and Young. 
Ettredge, M., Kwon, S., Smith, D., Zarowin, P., 2005. The impact of SFAS No.131 business segment data on the market's ability to anticipate future earnings. The Account. Rev. 80, 773-804.

Fan, Y., Barua, A., Cready, W.M., Thomas, W.B., 2010. Managing earnings using classification shifting: Evidence from quarterly special items. The Account. Rev. 85, 1303-1323.

Fields, T., Lys, T., Vincent, L., 2001. Empirical research on accounting choice. J. of Account. and Economics 31, 255-308.

Francis, J., Huang, A.H., Rajgopal, S., Zang, A.Y., 2008. CEO reputation and earnings quality. Contemporary Account. Res. 25, 109-147.

Francis, J., LaFond, R., Olsson, P.M., Schipper, K., 2004. Costs of equity and earnings attributes. The Account. Rev. 79, 967-1010.

Francis, J., LaFond, R., Olsson, P.M., Schipper, K., 2005. The market pricing of accruals quality. J. of Account. and Economics 39, 295-327.

Francis, J., Wang, D., 2008. The joint effect of investor protection and Big 4 audits on earnings quality around the world. Contemporary Account. Res. 25, 157-191.

Frankel, R., McVay, S., Soliman, M., 2011. Non-GAAP earnings and board independence. Rev. of Account. Stud. 16, 719-744.

Graham, J., Harvey, C., Rajgopal, S., 2005. The economic implications of corporate financial reporting. J. of Account. and Economics 40, 30-73.

Gunny, K., 2010. The relation between earnings management using real activities manipulation and future performance: Evidence from meeting earnings benchmarks. Contemporary Account. Res. 27, 855-888.

Habib, A., Gong, R., Hossain, M., 2013. Overvalued equities and audit fees: A research note. Managerial Auditing J. 28, 755-776.

Harris, T., Huh, E., Fairfield, P., 2000. Gauging Profitability on the Road to Valuation, Global Valuation and Accounting. Morgan Stanley Dean Witter, New York, NY.

Heflin, F., Hsu, C., 2008. The impact of the SEC's regulation of non-GAAP disclosures. J. of Account. and Economics 46, 349-365.

Hitz, J.M., 2010. Information versus strategic reporting: Determinants of the disclosure of pro forma earnings by large German corporations. J. für Betriebswirtschaft 60, 127-161. 
Houmes, R.E., Skantz, T.R., 2010. Highly valued equity and discretionary accruals. J. of Bus. Finance and Account. 37, 60-92.

How, J., Howe, J., 2001. The use of warrants in initial public offerings. J. of Bus. 74, $433-458$.

How, J., Lam, J., Yeo, J., 2007. The use of the comparable firm approach in valuing Australia IPOs. Int. Rev. of Financial Analysis 16, 99-115.

Isidro, H., Marques, A., 2014. The role of institutional and economic factors in the strategic use of non-GAAP disclosures to beat earnings benchmarks. Eur. Account. Rev. 24, 1-33.

Jennings, R., Marques, A., 2011. The joint effects of corporate governance and regulation on the disclosure of manager-adjusted non-GAAP earnings in the US. J. of Bus. Finance and Account. 38, 364-394.

Jensen, M., 2005. Agency costs of overvalued equity. Financial Manag. 34, 5-19.

Kim, M., Ritter, J., 1999. Valuing IPOs. J. of Financial Economics 53, 409-437.

KPMG, 2009. Underlying Profits Survey Report. KPMG, Australia.

KPMG, 2013. ASX50 Financial Reporting Insights. KPMG, Australia.

Laksmana, I., Yang, Y.W., 2014. Product market competition and earnings management: Evidence from discretionary accruals and real activity manipulation. Advances in Account. 30, 263-275.

Lont, D., Wong, N., Cheung, E., Evans, E., Wright, S., 2010. An historical review of quality in financial reporting in Australia. Pac. Account. Rev. 147-169.

Lougee, B.A., Marquardt, C.A., 2004. Earnings informativeness and strategic disclosure: An empirical examination of 'pro forma' earnings'. The Account. Rev. 79, 769-795.

Lundholm, R., Myers, L., 2002. Bringing the future forward: The effect of disclosure on the returns-earnings relation. J. of Account. Res. 40, 809-839.

Marciukaityte, D., Varma, R., 2008. Consequences of overvalued equity: Evidence from earnings manipulation. J. of Corporate Finance 14, 418-430.

Marques, A., 2006. SEC interventions and the frequency and usefulness of nonGAAP financial measures. Rev. of Account. Stud. 11, 549-574.

McVay, S., Nagar, V., Tang, V., 2006. Trading incentives to meet the analyst forecast. Rev. of Account. Stud. 11, 575-598. 
Mizik, N., Jacobson, R., 2007. Myopic marketing management: Evidence of the phenomenon and its long-term performance consequences in the SEO Context. Marketing Sci. 26, 361-379.

Nelson, M., Elliott, J., Tarpley, R., 2002. Evidence from auditors about managers' and auditors' earnings management decisions. The Account. Rev. 77, 175-202.

Nelson, M., Elliott, J., Tarpley, R., 2003. How are earnings managed? Examples from auditors. Account. Horizons 17, 17-35.

Palmrose, Z., Richardson, V., Scholz, S., 2004. Determinants of market reactions to restatement announcements. J. of Account and Economics 37, 59-89.

Securities and Exchange Commission (SEC), 2003. Final rule: Conditions for use of non-GAAP financial measures. Release Nos. 33-8176; 34-47226; FR-65; FILE NO. S7-43-02. Washington, DC: SEC.

Sek, J., Taylor, S., 2011. Profit or prophet? A case study of the reporting of nonGAAP earnings by Australian banks. Australian Account. Rev. 21, 327-339.

Skinner, D., Sloan, R., 2002. Earnings surprises, growth expectations, and stock returns or don't let an earnings torpedo sink your portfolio. Rev. of Account. Stud. 7, 289-312.

Woodside Petroleum Limited, 2012. Annual Report.

Xie, H., 2001. The mispricing of abnormal accruals. The Account. Rev. 76, 357-373.

Zang, A., 2012. Evidence on the trade-off between real activities manipulation and accrual based earning management. The Account. Rev. 87, 675-703. 


\section{Results tables}

Table 1: sample selection

\begin{tabular}{|c|c|}
\hline \multicolumn{2}{|l|}{ Sample selection } \\
\hline & Firm-year observations \\
\hline Top ASX200 firms & 1200 \\
\hline \multicolumn{2}{|l|}{ Exclusions: } \\
\hline Banks & 24 \\
\hline Insurance & 16 \\
\hline Diversified financials & 36 \\
\hline Real estate & 76 \\
\hline Missing data & 121 \\
\hline Final group investigated & 927 \\
\hline Underlying earnings reporting & 658 \\
\hline $\begin{array}{l}\text { Reported underlying earnings } \\
\text { are greater than statutory } \\
\text { earnings }\end{array}$ & 491 \\
\hline
\end{tabular}

Table 2: Descriptive statistics for variables

\begin{tabular}{lllllll}
\hline Variable & Observation & Mean & LowQ & Median & TopQ & Std. Dev. \\
\hline InAM $_{\mathrm{j}, \mathrm{t}}$ & 927 & 0.406 & 0.000 & 0.000 & 1.000 & 0.491 \\
$\mathrm{InEx}_{\mathrm{j}, \mathrm{t}}$ & 927 & 0.530 & 0.000 & 1.000 & 1.000 & 0.499 \\
$\mathrm{IND}_{\mathrm{j}, \mathrm{t}}$ & 927 & 0.697 & 0.600 & 0.750 & 0.833 & 0.171 \\
$\mathrm{PE}_{\mathrm{j}, \mathrm{t}}$ & 927 & 15.274 & 10.150 & 14.190 & 18.970 & 8.541 \\
$\mathrm{~PB}_{\mathrm{j}, \mathrm{t}}$ & 927 & 2.607 & 1.120 & 1.830 & 3.080 & 2.379 \\
$\mathrm{PBPE}_{\mathrm{j}, \mathrm{t}}$ & 927 & 8.940 & 5.870 & 8.190 & 11.285 & 4.759
\end{tabular}

Note: InAM $\mathrm{M}_{\mathrm{j}, \mathrm{t}}$ is positive of 'abnormal' accruals (the positive of residuals $\left(\mathrm{e}_{\mathrm{j}, \mathrm{t}}\right)$ from Equation (2)), which represents income-increasing accrual-based earnings management for firm $\mathrm{j}$, year $\mathrm{t}$. InEx $\mathrm{x}_{\mathrm{j}, \mathrm{t}}$ is a dummy variable which equals 1 if $\mathrm{j}$ firm discloses underlying earnings greater than statutory earnings in year $t$, and 0 otherwise. $\operatorname{IND}_{\mathrm{j}, \mathrm{t}}$ is percentage of independent directors on the board. $\mathrm{PE}_{\mathrm{j}, \mathrm{t}}$ is price-to-earnings ratio for $\mathrm{j}$ firm in year $\mathrm{t}$, which is collected from DatAnalysis database. $\mathrm{PB}_{\mathrm{j}, \mathrm{t}}$ is price-to-book ratio for $\mathrm{j}$ firm in year $\mathrm{t}$, which is collected from DatAnalysis database. $\mathrm{PBPE}_{\mathrm{j}, \mathrm{t}}$ is average of $\mathrm{PE}_{\mathrm{j}, \mathrm{t}}$ and $\mathrm{PB}_{\mathrm{j}, \mathrm{t}}$ for firm $\mathrm{j}$ in year $\mathrm{t}$. 
Table 3: Pearson and Spearman correlations and factor analysis

\begin{tabular}{|c|c|c|c|c|c|c|c|c|}
\hline & $\operatorname{InAM}_{\mathrm{j}, \mathrm{t}}$ & $\operatorname{InEx}_{\mathrm{j}, \mathrm{t}}$ & $\mathrm{IND}_{\mathrm{j}, \mathrm{t}}$ & Over $_{1 \mathrm{j}, \mathrm{t}}$ & Over $_{2 \mathrm{j}, \mathrm{t}}$ & Over $_{3 \mathrm{j}, \mathrm{t}}$ & Over $_{4 \mathrm{j}, \mathrm{t}}$ & Over $_{5 \mathrm{j}, \mathrm{t}}$ \\
\hline \multirow[t]{2}{*}{$\operatorname{InAM}_{\mathrm{j}, \mathrm{t}}$} & 1.000 & $-0.043^{* *}$ & 0.021 & $0.030^{* *}$ & $0.058^{* *}$ & 0.014 & 0.019 & 0.036 \\
\hline & & $(0.040)$ & $(0.525)$ & $(0.045)$ & $(0.048)$ & $(0.640)$ & $(0.518)$ & $(0.226)$ \\
\hline \multirow[t]{2}{*}{$\operatorname{InEx}_{\mathrm{j}, \mathrm{t}}$} & $-0.002^{* *}$ & 1.000 & $0.168^{* * *}$ & 0.015 & $0.009^{*}$ & $0.035^{* *}$ & $0.004^{* *}$ & $0.066^{* * *}$ \\
\hline & $(0.046)$ & & $(0.000)$ & $(0.620)$ & $(0.075)$ & $(0.029)$ & $(0.035)$ & $(0.001)$ \\
\hline \multirow[t]{2}{*}{$\mathrm{IND}_{\mathrm{j}, \mathrm{t}}$} & 0.021 & $0.176^{* * *}$ & 1.000 & $0.057^{*}$ & -0.022 & -0.016 & $-0.089^{* * *}$ & -0.008 \\
\hline & $(0.524)$ & $(0.000)$ & & $(0.083)$ & $(0.504)$ & $(0.619)$ & $(0.006)$ & $(0.816)$ \\
\hline \multirow[t]{2}{*}{ Over $_{1 \mathrm{j}, \mathrm{t}}$} & $0.023^{* *}$ & 0.010 & 0.052 & 1.000 & -0.019 & -0.013 & -0.017 & $-0.057^{*}$ \\
\hline & $(0.042)$ & $(0.750)$ & $(0.116)$ & & $(0.529)$ & $(0.658)$ & $(0.564)$ & $(0.052)$ \\
\hline \multirow[t]{2}{*}{ Over $_{2 \mathrm{j}, \mathrm{t}}$} & $0.071^{* *}$ & $0.002^{*}$ & -0.024 & -0.021 & 1.000 & -0.016 & -0.021 & $-0.071^{* *}$ \\
\hline & $(0.029)$ & $(0.081)$ & $(0.472)$ & $(0.527)$ & & $(0.583)$ & $(0.473)$ & $(0.016)$ \\
\hline \multirow[t]{2}{*}{ Over $_{3 \mathrm{j}, \mathrm{t}}$} & 0.008 & $0.036^{* *}$ & -0.021 & -0.015 & -0.019 & 1.000 & -0.015 & $-0.050^{*}$ \\
\hline & $(0.810)$ & $(0.027)$ & $(0.518)$ & $(0.657)$ & $(0.572)$ & & $(0.614)$ & $(0.090)$ \\
\hline \multirow[t]{2}{*}{ Over $_{4 \mathrm{j}, \mathrm{t}}$} & 0.015 & $0.019^{* *}$ & $-0.066^{* *}$ & -0.019 & -0.025 & -0.017 & 1.000 & $-0.065^{* *}$ \\
\hline & $(0.659)$ & $(0.045)$ & $(0.043)$ & $(0.555)$ & $(0.453)$ & $(0.598)$ & & $(0.027)$ \\
\hline \multirow[t]{2}{*}{ Over $_{5 \mathrm{j}, \mathrm{t}}$} & 0.006 & $0.104^{* * *}$ & -0.003 & $-0.065^{* *}$ & $-0.082^{* *}$ & $-0.058^{*}$ & $-0.077^{* *}$ & 1.000 \\
\hline & $(0.865)$ & $(0.002)$ & $(0.929)$ & $(0.047)$ & $(0.012)$ & $(0.077)$ & $(0.019)$ & \\
\hline
\end{tabular}

p-value in parentheses

${ }^{*} p<0.10,{ }^{* *} p<0.05,{ }^{* * *} p<0.01$

Pearson (above) and Spearman (below) correlations

\begin{tabular}{lllll}
\hline \multicolumn{5}{l}{ Table 3 Panel B: Factor analysis for overvaluation variables } \\
\hline Factor & Eigenvalue & Difference & Proportion & Cumulative \\
\hline Factor1 (PB ratios) & 1.182 & 0.365 & 0.5912 & 0.5912 \\
Factor2 (PE ratios) & 0.818 & 0.000 & 0.4088 & 1.0000 \\
Number of obs & 927 & & \\
Retained factors & 1 & & \\
Number of params & 1 & & \\
chi2(1) & 31.62 & & \\
Prob $>$ chi2 & 0 & & & \\
\hline
\end{tabular}

Note: Over $_{1 j, t}$ equals 1 if $\mathrm{j}$ firm is overvalued for one year during the sample years, and 0 otherwise. Over ${ }_{2 \mathrm{j}, \mathrm{t}}$ equals 1 if $\mathrm{j}$ firm is overvalued two consecutive years during the sample years, and 0 otherwise. Over $_{3 \mathrm{j}, \mathrm{t}}$ equals 1 if $\mathrm{j}$ firm is overvalued three consecutive years during the sample years, and 0 otherwise. Over ${ }_{4 j, t}$ equals 1 if $j$ firm is overvalued four consecutive years during the sample years, and 0 otherwise. Over $_{5, \mathrm{t}}$ equals 1 if $\mathrm{j}$ firm is overvalued five or more than five consecutive years during the sample years, and 0 otherwise. InAM $_{\mathrm{j}, \mathrm{t}}$ is positive of 'abnormal' accruals (the positive of residuals ( $\mathrm{e}_{\mathrm{j}, \mathrm{t}}$ ) from Equation (2)), which represents income-increasing accrual-based earnings management for firm $\mathrm{j}$, year $\mathrm{t}$. $\operatorname{InEx}_{\mathrm{j}, \mathrm{t}}$ is a dummy variable which equals 1 if $\mathrm{j}$ firm discloses underlying earnings greater than statutory earnings in year $t$, and 0 otherwise. $\mathrm{IND}_{\mathrm{j}, \mathrm{t}}$ is percentage of independent directors on the board. 
Table 4: Regression results for overvaluation and earnings management

(H1)

\begin{tabular}{|c|c|c|c|c|c|c|}
\hline & \multicolumn{3}{|c|}{ In $\mathrm{AM}_{\mathrm{j}, \mathrm{t}}$ as dependent variable } & \multicolumn{3}{|c|}{$\mathrm{InEx}_{\mathrm{j}, \mathrm{t}}$ as dependent variable } \\
\hline & Coef. & $\mathrm{z}$ & $\mathrm{P}>\mathrm{z}$ & Coef. & $\mathrm{z}$ & $\mathrm{P}>\mathrm{z}$ \\
\hline Over $_{1, \mathrm{t}}$ & $0.571^{* *}$ & 2.240 & 0.025 & 0.177 & 0.300 & 0.763 \\
\hline Over $_{2, \mathrm{t}}$ & $1.507^{*}$ & 1.850 & 0.065 & $0.783^{*}$ & 1.670 & 0.096 \\
\hline Over $_{3, t}$ & 0.912 & 1.200 & 0.293 & $0.877^{* * *}$ & 2.690 & 0.007 \\
\hline Over $_{4, \mathrm{t}}$ & -0.185 & -0.290 & 0.225 & $1.007^{* *}$ & 2.210 & 0.027 \\
\hline Over $_{5, \mathrm{t}}$ & -0.125 & -0.400 & 0.464 & $0.939^{* * *}$ & 3.090 & 0.002 \\
\hline \multicolumn{7}{|l|}{ AM specific } \\
\hline $\operatorname{Big} 4_{j, t}$ & $-0.888^{* *}$ & -2.110 & 0.035 & & & \\
\hline Litigation $_{\mathrm{j}, \mathrm{t}}$ & -0.952 & -1.560 & 0.119 & & & \\
\hline \multicolumn{7}{|l|}{ UE specific } \\
\hline Meet $_{j, t}$ & & & & $-0.514^{* * *}$ & -2.930 & 0.003 \\
\hline $\operatorname{Loss}_{\mathrm{j}, \mathrm{t}}$ & & & & $1.786^{* * *}$ & 6.760 & 0.000 \\
\hline \multicolumn{7}{|l|}{ General controls } \\
\hline $\operatorname{InEx}_{\mathrm{j}, \mathrm{t}}$ & $-0.766^{* * *}$ & -3.920 & 0.000 & & & \\
\hline $\operatorname{InAM}_{\mathrm{j}, \mathrm{t}}$ & & & & $-0.767^{* * *}$ & -3.950 & 0.000 \\
\hline Leverage $_{\mathrm{j}, \mathrm{t}}$ & 0.486 & 1.130 & 0.257 & $1.413^{* * *}$ & 2.960 & 0.003 \\
\hline Sales $\mathrm{G}_{\mathrm{j}, \mathrm{t}}$ & -0.158 & -0.410 & 0.680 & -0.146 & -0.400 & 0.687 \\
\hline $\mathrm{MtoB}_{\mathrm{j}, \mathrm{t}}$ & -0.111 & -1.550 & 0.121 & $-0.154^{* * *}$ & -3.010 & 0.003 \\
\hline Mktcap $_{\mathrm{j}, \mathrm{t}}$ & $0.183^{* * *}$ & 2.610 & 0.009 & 0.095 & 1.640 & 0.101 \\
\hline $\mathrm{NOA}_{\mathrm{j}, \mathrm{t}}$ & $-0.275^{*}$ & 1.880 & 0.060 & 0.002 & 0.240 & 0.807 \\
\hline $\mathrm{ROE}_{\mathrm{j}, \mathrm{t}}$ & -0.002 & -0.410 & 0.685 & 0.003 & 1.390 & 0.164 \\
\hline Capital $_{\mathrm{j}, \mathrm{t}}$ & 0.046 & 0.210 & 0.831 & -0.139 & -0.790 & 0.427 \\
\hline $\mathrm{IND}_{\mathrm{j}, \mathrm{t}}$ & 0.368 & 0.670 & 0.502 & $1.761^{* * *}$ & 3.690 & 0.000 \\
\hline _cons & -0.600 & -0.690 & 0.489 & $-1.642^{* *}$ & -2.440 & 0.015 \\
\hline Year effects & YES & & & YES & & \\
\hline Industry effects & YES & & & YES & & \\
\hline Number of obs & 927 & & & 927 & & \\
\hline Pseudo $\mathrm{R}^{2}$ & $28.30 \%$ & & & $17.00 \%$ & & \\
\hline
\end{tabular}

Note: Over $_{1 j, t}$ equals 1 if $\mathrm{j}$ firm is overvalued one year during the sample years, and 0 otherwise. Over $2 \mathrm{j,t}$ equals 1 if $\mathrm{j}$ firm is overvalued two consecutive years during the sample years, and 0 otherwise. Over ${ }_{3 j, t}$ equals 1 if $\mathrm{j}$ firm is overvalued three consecutive years during the sample years, and 0 otherwise. Over ${ }_{4 j, t}$ equals 1 if $\mathrm{j}$ firm is overvalued four consecutive years during the sample years, and 0 otherwise. Over $r_{5, t, t}$ equals 1 if $j$ firm is overvalued five or more than five consecutive years during the sample years, and 0 otherwise. InAM $_{\mathrm{j}, \mathrm{t}}$ is positive of 'abnormal' accruals (the positive of residuals $\left(\mathrm{e}_{\mathrm{j}, \mathrm{t}}\right)$ from Equation (2)), which represents income-increasing accrual-based earnings management for firm $\mathrm{j}$, year $\mathrm{t}$. $\mathrm{InEx}_{\mathrm{j}, \mathrm{t}}$ is a dummy variable which equals 1 if $\mathrm{j}$ firm discloses underlying earnings greater than statutory earnings in year $t$, and 0 otherwise. Size $e_{j, t}$ is natural logarithm of the total assets for firm $\mathrm{j}$, year $\mathrm{t}$; Opcycle $\mathrm{j}_{\mathrm{j}, \mathrm{t}}$ is natural logarithm of days of accounts receivable plus days of inventory for firm $\mathrm{j}$, year $\mathrm{t} ; \mathrm{Cfo}_{\mathrm{j}, \mathrm{t}}$ is standard deviation of cash flows from operations scaled by beginning total assets, computed using a 5-year rolling window ended in year 2012 for firm $j$, year $t$; Sales $_{\mathrm{j}, \mathrm{t}}$ is standard deviation of sales revenue scaled by beginning total assets, computed using a 5-year rolling window ended in 2012 for firm $\mathrm{j}$, year t; NegEarn $_{j, t}$ is firm's proportion of losses over the prior 5 years for firm $j$, year $t$. Big $4_{j, t}$ equals 1 if $j$ firm is audited by Big 4 auditors, and 0 otherwise. $\mathrm{SDE}_{\mathrm{j}, \mathrm{t}}$ is measured by standard deviation of earnings before tax using a 5 -year rolling window ending in 2012 for firm $\mathrm{j}$, year t. Litigation $n_{\mathrm{j}, \mathrm{t}}$ equals 1 if $\mathrm{j}$ firm is in pharmaceuticals/biotechnology, software, or services industries, and 0 otherwise. Meet $t_{j, t}$ is a dummy variable that equals 1 if $\mathrm{j}$ firm's earnings before tax in year $\mathrm{t}$ is greater than or equals to earnings before tax in year $\mathrm{t}-1$, and 0 otherwise. $\operatorname{Loss}_{\mathrm{j}, \mathrm{t}}$ is a dummy variable that equals 1 if $\mathrm{j}$ firm reports statutory earnings in year $t$, and 0 otherwise. $\mathrm{MtoB}_{\mathrm{j}, \mathrm{t}}$ is the market-to-book equity ratio for firm $\mathrm{j}$ in year $\mathrm{t}$. $\mathrm{ROE}_{\mathrm{j}, \mathrm{t}}$ is earnings before tax divided by average equity for firm $\mathrm{j}$ in year $\mathrm{t}$. 
Leverage $e_{j, t}$ is measured by short-term and long-term debt divided by total assets for firm $j$, year t. $\operatorname{NOA}_{j, t}$ is measured by shareholders' equity less cash and cash equivalent plus total debt at the beginning of the year divided by lagged sales. Sales $\mathrm{G}_{\mathrm{j}, \mathrm{t}}$ is the sales for firm $\mathrm{j}$, year $\mathrm{t}$ minus the sales for firm $\mathrm{j}$, year $\mathrm{t}-1$, then divided by the sales for firm $\mathrm{j}$, year t. MktCap $\mathrm{j}_{\mathrm{t}, \mathrm{t}}$ is measured as the natural logarithm of the market capitalisation of the firm at the beginning of year $t$ for firm $j$. Capital $\mathrm{j}_{\mathrm{j}, \mathrm{t}}$ is capital intensity measured by the ratio of net book value of property, plant, and equipment to total assets for firm $\mathrm{j}$, year $\mathrm{t} . \mathrm{IND}_{\mathrm{j}, \mathrm{t}}$ is percentage of independent directors on the board. 
Table 5: Regression results for impact of corporate governance on overvaluation and earnings management (H2)

\begin{tabular}{|c|c|c|c|c|}
\hline & \multicolumn{2}{|c|}{$\begin{array}{l}\text { Firms with a high proportion of } \\
\text { independent directors on the board }\end{array}$} & \multicolumn{2}{|c|}{$\begin{array}{l}\text { Firms with a low proportion of } \\
\text { independent directors on the board }\end{array}$} \\
\hline & InAM & InEx & InAM & InEx \\
\hline & Coef. & Coef. & Coef. & Coef. \\
\hline \multirow[t]{2}{*}{ Over $_{1 j, t}$} & $0.866^{*}$ & -0.833 & $2.110^{* *}$ & 0.067 \\
\hline & $(0.096)$ & $(0.317)$ & $(0.053)$ & $(0.931)$ \\
\hline \multirow[t]{2}{*}{ Over $_{2, \mathrm{t}}$} & 1.379 & 0.118 & $1.572^{* *}$ & 0.453 \\
\hline & $(0.284)$ & $(0.697)$ & $(0.022)$ & $(0.476)$ \\
\hline \multirow[t]{2}{*}{ Over $_{3 \mathrm{j}, \mathrm{t}}$} & -1.243 & 0.848 & $2.493^{* * *}$ & $2.176^{* *}$ \\
\hline & $(0.611)$ & $(0.974)$ & $(0.004)$ & $(0.034)$ \\
\hline \multirow[t]{2}{*}{ Over $_{4 j, t}$} & 1.425 & $0.057^{* *}$ & $2.058^{* *}$ & $0.112^{* *}$ \\
\hline & $(0.272)$ & $(0.043)$ & $(0.010)$ & $(0.049)$ \\
\hline \multirow[t]{2}{*}{ Over $_{5, \mathrm{t}}$} & 0.359 & $0.232^{* *}$ & 0.641 & $0.586^{* * *}$ \\
\hline & $(0.400)$ & $(0.020)$ & $(0.551)$ & $(0.000)$ \\
\hline \multicolumn{5}{|c|}{ AM specific } \\
\hline \multirow[t]{2}{*}{$\operatorname{Big} 4_{j, t}$} & $1.981^{* *}$ & & 0.571 & \\
\hline & $(0.025)$ & & $(0.478)$ & \\
\hline \multirow[t]{2}{*}{ Litigation $_{\mathrm{j}, \mathrm{t}}$} & 2.706 & & -0.081 & \\
\hline & $(0.988)$ & & $(0.943)$ & \\
\hline \multicolumn{5}{|l|}{ UE specific } \\
\hline \multirow[t]{2}{*}{ Meet $_{j, t}$} & & -0.123 & & $-0.699^{*}$ \\
\hline & & $(0.636)$ & & $(0.084)$ \\
\hline \multirow[t]{2}{*}{$\operatorname{Loss}_{\mathrm{j}, \mathrm{t}}$} & & $0.923^{* * *}$ & & $1.025^{* *}$ \\
\hline & & $(0.002)$ & & $(0.060)$ \\
\hline \multicolumn{5}{|c|}{ General controls } \\
\hline \multirow[t]{2}{*}{$\operatorname{InEx} x_{j, t}$} & $-0.689^{* *}$ & & 0.477 & \\
\hline & $(0.049)$ & & $(0.304)$ & \\
\hline \multirow[t]{2}{*}{$\operatorname{In} \mathrm{AM}_{\mathrm{j}, \mathrm{t}}$} & & $-0.886^{* *}$ & & -0.514 \\
\hline & & $(0.012)$ & & $(0.272)$ \\
\hline \multirow[t]{2}{*}{ Leverage $_{\mathrm{j}, \mathrm{t}}$} & $1.603^{* *}$ & 0.573 & 0.852 & 0.737 \\
\hline & $(0.042)$ & $(0.245)$ & $(0.350)$ & $(0.370)$ \\
\hline \multirow[t]{2}{*}{ SalesG $\mathrm{j}_{\mathrm{j}, \mathrm{t}}$} & -0.111 & 0.008 & 0.225 & 0.796 \\
\hline & $(0.481)$ & $(0.933)$ & $(0.772)$ & $(0.260)$ \\
\hline \multirow[t]{2}{*}{ MtoB $_{\mathrm{j}, \mathrm{t}}$} & 0.019 & 0.013 & $-0.495^{* * *}$ & -0.100 \\
\hline & $(0.836)$ & $(0.343)$ & $(0.004)$ & $(0.487)$ \\
\hline \multirow[t]{2}{*}{ Mktcap $_{j, t}$} & $0.220^{* *}$ & $0.364^{* * *}$ & $-0.397^{*}$ & 0.083 \\
\hline & $(0.038)$ & $(0.000)$ & $(0.076)$ & $(0.587)$ \\
\hline \multirow[t]{2}{*}{$\mathrm{NOA}_{\mathrm{j}, \mathrm{t}}$} & $-0.008^{*}$ & 0.002 & $-0.566^{*}$ & 0.054 \\
\hline & $(0.096)$ & $(0.797)$ & $(0.093)$ & $(0.723)$ \\
\hline \multirow[t]{2}{*}{$\mathrm{ROE}_{\mathrm{j}, \mathrm{t}}$} & 0.004 & 0.009 & 0.007 & -0.020 \\
\hline & $(0.648)$ & $(0.940)$ & $(0.664)$ & $(0.410)$ \\
\hline \multirow[t]{2}{*}{ Capital $_{j, t}$} & 0.058 & $0.458^{* * *}$ & 0.625 & -0.236 \\
\hline & $(0.716)$ & $(0.002)$ & $(0.256)$ & $(0.614)$ \\
\hline \multirow[t]{2}{*}{ _cons } & $-5.017^{* * *}$ & $-3.929^{* * *}$ & 2.140 & 0.368 \\
\hline & $(0.000)$ & $(0.000)$ & $(0.323)$ & $(0.815)$ \\
\hline
\end{tabular}




\begin{tabular}{lllll}
\hline Table 5 continued & \multicolumn{3}{l}{} \\
\hline Year effects & YES & YES & YES & YES \\
Industry effects & YES & YES & YES & YES \\
Number of obs & 232 & 232 & 232 & 232 \\
Pseudo $\mathrm{R}^{2}$ & $42.4 \%$ & $21.2 \%$ & $39.0 \%$ & $17.7 \%$ \\
\hline${ }^{*} p<0.10{ }^{* *} p<0.05,{ }^{* * *} p<0.01 \mathrm{p}$-Value in parentheses & &
\end{tabular}

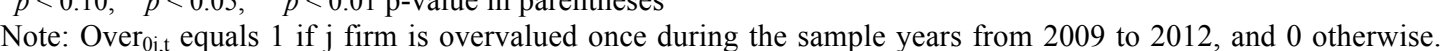
Over $_{1 \mathrm{j}, \mathrm{t}}$ equals 1 if $\mathrm{j}$ firm is overvalued one year during the sample years, and 0 otherwise. Over $2 \mathrm{j,t}$ equals 1 if $\mathrm{j}$ firm is overvalued two consecutive years during the sample years, and 0 otherwise. Over ${ }_{3 j, t}$ equals 1 if $j$ firm is overvalued three consecutive years during the sample years, and 0 otherwise. Over ${ }_{4 j, t}$ equals 1 if $j$ firm is overvalued four consecutive years during the sample years, and 0 otherwise. Over $_{5 j, t}$ equals 1 if $\mathrm{j}$ firm is overvalued five or more than five consecutive years during the sample years, and 0 otherwise. InAM $\mathrm{M}_{\mathrm{j}, \mathrm{t}}$ is positive of 'abnormal' accruals (the positive of residuals $\left(\mathrm{e}_{\mathrm{j}, \mathrm{t}}\right)$ from Equation (2)), which represents income-increasing accrual-based earnings management for firm $j$, year $t$. InEx $x_{j, t}$ is a dummy variable which equals 1 if $j$ firm discloses underlying earnings greater than statutory earnings in year $t$, and 0 otherwise. Big $4_{j, t}$ equals 1 if $j$ firm is audited by Big 4 auditors, and 0 otherwise. Litigation ${ }_{\mathrm{j}, \mathrm{t}}$ equals 1 if $\mathrm{j}$ firm is in pharmaceuticals/biotechnology, software, or services industries, and 0 otherwise. Meet $_{\mathrm{j}, \mathrm{t}}$ is a dummy variable that equals 1 if $\mathrm{j}$ firm's earnings before tax in year $t$ is greater than or equal to earnings before tax in year $t-1$, and 0 otherwise. Loss $\mathrm{j}_{\mathrm{j}, \mathrm{t}}$ is a dummy variable that equals 1 if $\mathrm{j}$ firm reports statutory earnings in year $\mathrm{t}$, and 0 otherwise. $M \mathrm{MtoB}_{\mathrm{j}, \mathrm{t}}$ is the market-to-book equity ratio for firm $\mathrm{j}$ in year $t . \mathrm{ROE}_{\mathrm{j}, \mathrm{t}}$ is earnings before tax divided by average equity for firm $\mathrm{j}$ in year $\mathrm{t}$. Leverage $\mathrm{j}_{\mathrm{j}, \mathrm{t}}$ is measured by short-term and long-term debt divided by total assets for firm $\mathrm{j}$, year t. $\mathrm{NOA}_{\mathrm{j}, \mathrm{t}}$ is measured by shareholders' equity less cash and cash equivalent plus total debt at the beginning of the year divided by lagged sales. $\mathrm{Sales}_{\mathrm{j}, \mathrm{t}}$ is the sales for firm $j$, year $t$ minus the sales for firm $j$, year $t-1$, then divided by the sales for firm $j$, year $t$. MktCap $p_{j, t}$ is measured as the natural logarithm of the market capitalisation of the firm at the beginning of year $t$ for firm $j$. Capital $_{\mathrm{j}, \mathrm{t}}$ is capital intensity measured by the ratio of net book value of property, plant, and equipment to total assets for firm $\mathrm{j}$, year $\mathrm{t}$. 
Table 6: Regression results for impact of ASIC underlying earnings disclosure guidelines on overvaluation and earnings management (H3)

\begin{tabular}{|c|c|c|c|c|}
\hline & \multicolumn{2}{|c|}{$\begin{array}{l}\text { Firms that voluntarily conform to the } \\
\text { guidelines }\end{array}$} & \multicolumn{2}{|c|}{$\begin{array}{l}\text { Firms that do not voluntarily } \\
\text { conform to the guidelines }\end{array}$} \\
\hline & InAM & $\operatorname{InEx}$ & InAM & InEx \\
\hline & Coef. & Coef. & Coef. & Coef. \\
\hline \multirow[t]{2}{*}{ Over $_{1 \mathrm{j}, \mathrm{t}}$} & 0.907 & 0.269 & $4.102^{* *}$ & 1.095 \\
\hline & $(0.256)$ & $(0.537)$ & $(0.050)$ & $(0.463)$ \\
\hline \multirow[t]{2}{*}{ Over $_{2 \mathrm{j}, \mathrm{t}}$} & 1.167 & $0.897^{* *}$ & $2.778^{* * *}$ & $1.442^{* * *}$ \\
\hline & $(0.162)$ & $(0.046)$ & $(0.003)$ & $(0.007)$ \\
\hline \multirow[t]{2}{*}{ Over $_{3 \mathrm{j}, \mathrm{t}}$} & 0.529 & 0.272 & $0.313^{*}$ & $2.797^{* * *}$ \\
\hline & $(0.537)$ & $(0.556)$ & $(0.061)$ & $(0.003)$ \\
\hline \multirow[t]{2}{*}{ Over $_{4 \mathrm{j}, \mathrm{t}}$} & 1.543 & -1.138 & -0.596 & $0.983^{* *}$ \\
\hline & $(0.397)$ & $(0.113)$ & $(0.455)$ & $(0.056)$ \\
\hline \multicolumn{5}{|l|}{ AM specific } \\
\hline \multirow[t]{2}{*}{$B i g 4_{j, t}$} & $-0.571^{* *}$ & & -0.204 & \\
\hline & $(0.025)$ & & $(0.820)$ & \\
\hline \multirow[t]{2}{*}{ Litigation $_{\mathrm{j}, \mathrm{t}}$} & $-2.116^{* * *}$ & & $-2.870^{* * *}$ & \\
\hline & $(0.002)$ & & $(0.002)$ & \\
\hline \multicolumn{5}{|l|}{ UE specific } \\
\hline \multirow[t]{2}{*}{ Meet $_{j, t}$} & & -0.624 & & $-1.085^{* * *}$ \\
\hline & & $(0.211)$ & & $(0.004)$ \\
\hline \multirow[t]{2}{*}{$\operatorname{Loss}_{\mathrm{j}, \mathrm{t}}$} & & $3.189^{* * *}$ & & $2.650^{* * *}$ \\
\hline & & $(0.000)$ & & $(0.000)$ \\
\hline \multicolumn{5}{|c|}{ General controls } \\
\hline \multirow[t]{2}{*}{$\operatorname{InEx}_{\mathrm{j}, \mathrm{t}}$} & -1.764 & & $1.839^{* *}$ & \\
\hline & $(0.268)$ & & $(0.018)$ & \\
\hline \multirow[t]{2}{*}{$\operatorname{In} \mathrm{AM}_{\mathrm{j}, \mathrm{t}}$} & & -0.581 & & $1.522^{* *}$ \\
\hline & & $(0.611)$ & & $(0.018)$ \\
\hline \multirow[t]{2}{*}{ Leverage $_{\mathrm{j}, \mathrm{t}}$} & 0.931 & $5.010^{* *}$ & 0.702 & $2.880^{* *}$ \\
\hline & $(0.818)$ & $(0.014)$ & $(0.773)$ & $(0.015)$ \\
\hline \multirow[t]{2}{*}{ Sales $G_{j, t}$} & 0.489 & 0.753 & $-3.195^{*}$ & 0.731 \\
\hline & $(0.911)$ & $(0.599)$ & $(0.051)$ & $(0.358)$ \\
\hline \multirow[t]{2}{*}{ MtoB $_{\mathrm{j}, \mathrm{t}}$} & 0.469 & 0.091 & -0.100 & $-0.241^{* * *}$ \\
\hline & $(0.479)$ & $(0.653)$ & $(0.476)$ & $(0.006)$ \\
\hline \multirow[t]{2}{*}{ Mktcap $_{\mathrm{j}, \mathrm{t}}$} & 0.433 & -0.127 & 0.445 & -0.067 \\
\hline & $(0.504)$ & $(0.577)$ & $(0.125)$ & $(0.576)$ \\
\hline \multirow[t]{2}{*}{$\mathrm{NOA}_{\mathrm{j}, \mathrm{t}}$} & $-1.787^{* *}$ & 0.331 & $-0.793^{* *}$ & 0.001 \\
\hline & $(0.041)$ & $(0.162)$ & $(0.031)$ & $(0.928)$ \\
\hline \multirow[t]{2}{*}{$\mathrm{ROE}_{\mathrm{j}, \mathrm{t}}$} & 0.005 & 0.005 & -0.006 & 0.006 \\
\hline & $(0.850)$ & $(0.434)$ & $(0.659)$ & $(0.257)$ \\
\hline \multirow[t]{2}{*}{ Capital $_{\mathrm{j}, \mathrm{t}}$} & 8.492 & 0.479 & 0.272 & $-1.362^{* *}$ \\
\hline & $(0.158)$ & $(0.764)$ & $(0.810)$ & $(0.047)$ \\
\hline \multirow[t]{2}{*}{$\mathrm{IND}_{\mathrm{j}, \mathrm{t}}$} & $-8.646^{* *}$ & 0.187 & 4.831 & 1.071 \\
\hline & $(0.015)$ & $(0.910)$ & $(0.162)$ & $(0.226)$ \\
\hline \multirow[t]{2}{*}{ _cons } & -8.771 & 1.382 & -1.868 & $2.808^{* *}$ \\
\hline & $(0.114)$ & $(0.499)$ & $(0.450)$ & $(0.027)$ \\
\hline
\end{tabular}




\begin{tabular}{lllll}
\hline Table 6 continued & & & & \\
\hline Year effects & YES & YES & YES & YES \\
Industry effects & YES & YES & YES & YES \\
Number of obs & 152 & 152 & 187 & 187 \\
Pseudo ${ }^{2}$ & $47.0 \%$ & $26.6 \%$ & $31.9 \%$ & $29.4 \%$ \\
\hline
\end{tabular}

${ }^{*} p<0.10,{ }^{* *} p<0.05,{ }^{* * *} p<0.01 \mathrm{p}$-value in parentheses

Note: Over $_{0 \mathrm{j}, \mathrm{t}}$ equals 1 if $\mathrm{j}$ firm is overvalued once during the sample years from 2009 to 2012 , and 0 otherwise. Over $_{1 \mathrm{j}, \mathrm{t}}$ equals 1 if $\mathrm{j}$ firm is overvalued one year during the sample years, and 0 otherwise. Over $2 \mathrm{j,t}$ equals 1 if $\mathrm{j}$ firm is overvalued two consecutive years during the sample years, and 0 otherwise. Over ${ }_{3 j, t}$ equals 1 if $\mathrm{j}$ firm is overvalued three consecutive years during the sample years, and 0 otherwise. Over ${ }_{4 j, t}$ equals 1 if $\mathrm{j}$ firm is overvalued four consecutive years during the sample years, and 0 otherwise. Over $r_{5, \mathrm{j}, \mathrm{t}}$ equals 1 if $\mathrm{j}$ firm is overvalued five or more than five consecutive years during the sample years, and 0 otherwise. $\operatorname{InAM}_{\mathrm{j}, \mathrm{t}}$ is positive of 'abnormal' accruals (the positive of residuals ( $\mathrm{e}_{\mathrm{j}, \mathrm{t}}$ ) from Equation (2)), which represents income-increasing accrual-based earnings management for firm $j$, year $t$. $\operatorname{InEx}_{j, t}$ is a dummy variable which equals 1 if $j$ firm discloses underlying earnings greater than statutory earnings in year $t$, and 0 otherwise. Big $4_{j, t}$ equals 1 if $j$ firm is audited by Big 4 auditors, ad 0 otherwise. Litigation ${ }_{\mathrm{j}, \mathrm{t}}$ equals 1 if $\mathrm{j}$ firm is in pharmaceuticals/biotechnology, software, or services industries, and 0 otherwise. Meet $\mathrm{j}_{\mathrm{j}, \mathrm{t}}$ is a dummy variable that equals 1 if $\mathrm{j}$ firm's earnings before tax in year $\mathrm{t}$ is greater than or equal to earnings before tax in year $\mathrm{t}-1$, and 0 otherwise. $\operatorname{Loss}_{\mathrm{j}, \mathrm{t}}$ is a dummy variable that equals 1 if $\mathrm{j}$ firm reports statutory earnings in year $\mathrm{t}$, and 0 otherwise. $\mathrm{MtoB}_{\mathrm{j}, \mathrm{t}}$ is the market-to-book equity ratio for firm $\mathrm{j}$ in year t. $\mathrm{ROE}_{\mathrm{j}, \mathrm{t}}$ is earnings before tax divided by average equity for firm $\mathrm{j}$ in year $\mathrm{t}$. Leverage $\mathrm{e}_{\mathrm{j}, \mathrm{t}}$ is measured by short-term and long-term debt divided by total assets for firm $\mathrm{j}$, year $\mathrm{t}$. $\mathrm{NOA}_{\mathrm{j}, \mathrm{t}}$ is measured by shareholders' equity less cash and cash equivalent plus total debt at the beginning of the year divided by lagged sales. $\mathrm{Sales}_{\mathrm{j}, \mathrm{t}}$ is the sales for firm $\mathrm{j}$, year $\mathrm{t}$ minus the sales for firm $\mathrm{j}$, year $\mathrm{t}-1$, then divided by the sales for firm $\mathrm{j}$, year $\mathrm{t}$. MktCap $\mathrm{p}_{\mathrm{j}, \mathrm{t}}$ is measured as the natural logarithm of the market capitalisation of the firm at the beginning of year $t$ for firm $\mathrm{j}$. Capital $_{\mathrm{j}, \mathrm{t}}$ is capital intensity measured by the ratio of net book value of property, plant, and equipment to total assets for firm j, year t. Limit the observations that report underlying earnings from 2013 to 2016 (total 339; 38 firms conform to guidelines over four years, leaving 187 observations as non-compliance firms). 
Table 7: Regression results for additional analysis (limited ability of using accrual-based earnings management)

\begin{tabular}{|c|c|c|c|c|c|c|}
\hline & \multicolumn{3}{|c|}{ InAM $_{\mathrm{j}, \mathrm{t}}$ as dependent variable } & \multicolumn{3}{|c|}{$\mathrm{InEx}_{\mathrm{j}, \mathrm{t}}$ as dependent variable } \\
\hline & Coef. & $\mathrm{z}$ & $\mathrm{P}>\mathrm{z}$ & Coef. & $\mathrm{z}$ & $\mathrm{P}>\mathrm{z}$ \\
\hline Over $_{1, j, t}$ & 0.726 & 1.190 & 0.138 & 0.629 & 0.070 & 0.393 \\
\hline Over $_{2 \mathrm{j}, \mathrm{t}}$ & $-0.205^{* *}$ & 4.190 & 0.020 & $0.515^{* *}$ & 2.040 & 0.042 \\
\hline Over $_{3, \mathrm{t}}$ & -2.275 & 2.710 & 0.950 & $0.790^{* * *}$ & 5.850 & 0.008 \\
\hline Over $_{4, \mathrm{t}}$ & -1.613 & -1.040 & 0.297 & $1.855^{* *}$ & 2.040 & 0.042 \\
\hline Over $_{j, t}$ & 1.535 & 1.200 & 0.230 & $0.807^{* * *}$ & 5.980 & 0.000 \\
\hline \multicolumn{7}{|l|}{ AM specific } \\
\hline $\operatorname{Big} 4_{j, t}$ & -0.804 & -0.910 & 0.360 & & & \\
\hline Litigation $_{\mathrm{j}, \mathrm{t}}$ & $2.204^{* *}$ & 1.960 & 0.050 & & & \\
\hline \multicolumn{7}{|l|}{ UE specific } \\
\hline Meet $_{\mathrm{j}, \mathrm{t}}$ & & & & -0.345 & -0.880 & 0.378 \\
\hline $\operatorname{Loss}_{\mathrm{j}, \mathrm{t}}$ & & & & $3.267^{* * *}$ & 4.060 & 0.000 \\
\hline \multicolumn{7}{|l|}{ General controls } \\
\hline $\operatorname{InEx}_{\mathrm{j}, \mathrm{t}}$ & $-0.708^{* *}$ & -2.200 & 0.028 & & & \\
\hline $\operatorname{InAM}_{\mathrm{j}, \mathrm{t}}$ & & & & -0.422 & -1.240 & 0.216 \\
\hline Leverage $_{\mathrm{j}, \mathrm{t}}$ & 1.037 & 1.060 & 0.287 & 1.012 & 0.970 & 0.332 \\
\hline SalesG $_{\mathrm{j}, \mathrm{t}}$ & -0.586 & -0.760 & 0.450 & 0.160 & 0.190 & 0.850 \\
\hline MtoB $_{\mathrm{j}, \mathrm{t}}$ & 0.005 & 0.020 & 0.984 & $-0.783^{* * *}$ & -3.070 & 0.002 \\
\hline Mktcap $_{\mathrm{j}, \mathrm{t}}$ & 0.020 & 0.150 & 0.881 & $0.445^{* * *}$ & 2.910 & 0.004 \\
\hline $\mathrm{ROE}_{\mathrm{j}, \mathrm{t}}$ & -0.610 & -0.310 & 0.754 & -0.409 & -0.200 & 0.844 \\
\hline Capital $_{j, t}$ & -0.477 & -1.280 & 0.201 & $1.194^{* * *}$ & 2.880 & 0.004 \\
\hline $\mathrm{IND}_{\mathrm{j}, \mathrm{t}}$ & -1.156 & -1.200 & 0.230 & 0.798 & 0.780 & 0.435 \\
\hline _cons. & -5.980 & -1.380 & 0.166 & -1.390 & 0.730 & 0.467 \\
\hline Year effects & YES & & & YES & & \\
\hline Industry effects & YES & & & YES & & \\
\hline Number of obs & 232 & & & 232 & & \\
\hline Pseudo $\mathrm{R}^{2}$ & $47.00 \%$ & & & $24.50 \%$ & & \\
\hline
\end{tabular}

Note: Over ${ }_{1 \mathrm{j}, \mathrm{t}}$ equals 1 if $\mathrm{j}$ firm is overvalued one year during the sample years, and 0 otherwise. Over $\mathrm{j}_{2 \mathrm{j}, \mathrm{t}}$ equals 1 if $\mathrm{j}$ firm is overvalued two consecutive years during the sample years, and 0 otherwise. Over ${ }_{3 j, t}$ equals 1 if $j$ firm is overvalued three consecutive years during the sample years, and 0 otherwise. Over $\mathrm{r}_{4 \mathrm{j}, \mathrm{t}}$ equals 1 if $\mathrm{j}$ firm is overvalued four consecutive years during the sample years, and 0 otherwise. Over $r_{5 j, t}$ equals 1 if $j$ firm is overvalued five or more than five consecutive years during the sample years, and 0 otherwise. InAM $_{\mathrm{j}, \mathrm{t}}$ is positive of 'abnormal' accruals (the positive of residuals $\left(\mathrm{e}_{\mathrm{j}, \mathrm{t}}\right)$ from Equation (2)), which represents income-increasing accrual-based earnings management for firm $\mathrm{j}$, year $\mathrm{t}$. $\operatorname{InEx}_{\mathrm{j}, \mathrm{t}}$ is a dummy variable which equals 1 if $\mathrm{j}$ firm discloses underlying earnings greater than statutory earnings in year $t$, and 0 otherwise. Big $4_{j, t}$ equals 1 if $j$ firm is audited by Big 4 auditors, and 0 otherwise. Litigation $n_{j, t}$ equals 1 if $\mathrm{j}$ firm is in pharmaceuticals/biotechnology, software, or services industries, and 0 otherwise. Meet $t_{j, t}$ is a dummy variable that equals 1 if $j$ firm's earnings before tax in year $t$ is greater than or equal to earnings before tax in year $t-1$, and 0 otherwise. Loss $s_{j, t}$ is a dummy variable that equals 1 if $\mathrm{j}$ firm report statutory earnings in year $\mathrm{t}$, and 0 otherwise. Mto $\mathrm{B}_{\mathrm{j}, \mathrm{t}}$ is the market-to-book equity ratio for firm $\mathrm{j}$ in year $t . R E_{j, t}$ is earnings before tax divided by average equity for firm $\mathrm{j}$ in year t. Leverage $\mathrm{e}_{\mathrm{j}, \mathrm{t}}$ is measured by short-term and long-term debt divided by total assets for firm $j$, year t. Sales $\mathrm{G}_{\mathrm{j}, \mathrm{t}}$ is the sales for firm $\mathrm{j}$, year $\mathrm{t}$ minus the sales for firm $\mathrm{j}$, year $\mathrm{t}-1$, then divided by the sales for firm $\mathrm{j}$, year $\mathrm{t}$. MktCap $\mathrm{p}_{\mathrm{j}, \mathrm{t}}$ is measured as the natural logarithm of the market capitalisation of the firm at the beginning of year $t$ for firm $j$. Capital ${ }_{j, t}$ is capital intensity measured by the ratio of net book value of property, plant, and equipment to total assets for firm $\mathrm{j}$, year $\mathrm{t}$. 


\section{Appendix one}

Variables definitions and measurements

\begin{tabular}{|c|c|c|}
\hline Variable & Proxy & Measurement \\
\hline \multicolumn{3}{|c|}{ Dependent variables } \\
\hline $\operatorname{InAM}_{\mathrm{j}, \mathrm{t}}$ & $\begin{array}{l}\text { Income increasing earnings included in } \\
\text { accrual-based earnings management }\end{array}$ & $\begin{array}{l}\text { Dummy variable, positive abnormal accruals } \\
\text { are coded as ' } 1 \text { ' and ' } 0 \text { ' otherwise }\end{array}$ \\
\hline $\operatorname{InEx}_{\mathrm{j}, \mathrm{t}}$ & Aggressive underlying earnings & $\begin{array}{l}\text { Dummy variable, underlying earnings greater } \\
\text { than statutory earnings is coded as ' } 1 \text { ' and ' } 0 \text { ' } \\
\text { otherwise }\end{array}$ \\
\hline \multicolumn{3}{|c|}{ Independent variables $\mathrm{H} 1$} \\
\hline Over $_{1 \mathrm{j}, \mathrm{t}}$ & $\begin{array}{l}\text { Market-based equity is overvalued for } \\
\text { one year, during the sample years }\end{array}$ & $\begin{array}{l}\text { Dummy variable, overvalued for one year, } \\
\text { equals ' } 1 \text { ' and ' } 0 \text { ' otherwise }\end{array}$ \\
\hline Over $_{2, \mathrm{t}}$ & $\begin{array}{l}\text { Market-based equity is overvalued for } \\
\text { two consecutive years, during the } \\
\text { sample years }\end{array}$ & $\begin{array}{l}\text { Dummy variable, overvalued for two } \\
\text { consecutive years, equals ' } 1 \text { ' and ' } 0 \text { ' otherwise }\end{array}$ \\
\hline Over $_{3 j, t}$ & $\begin{array}{l}\text { Market-based equity is overvalued for } \\
\text { three consecutive years, during the } \\
\text { sample years }\end{array}$ & $\begin{array}{l}\text { Dummy variable, overvalued for three } \\
\text { consecutive years, equals ' } 1 \text { ' and ' } 0 \text { ' otherwise }\end{array}$ \\
\hline Over $_{4, \mathrm{j}, \mathrm{t}}$ & $\begin{array}{l}\text { Market-based equity is overvalued for } \\
\text { four consecutive years, during the } \\
\text { sample years }\end{array}$ & $\begin{array}{l}\text { Dummy variable, overvalued for four } \\
\text { consecutive years, equals ' } 1 \text { ' and ' } 0 \text { ' otherwise }\end{array}$ \\
\hline \multicolumn{3}{|c|}{ Independent variable $\mathrm{H} 2$} \\
\hline $\mathrm{IND}_{\mathrm{j}, \mathrm{t}}$ & $\begin{array}{l}\text { Extent of independent directors on } \\
\text { board }\end{array}$ & $\begin{array}{l}\text { Percent of independent directors over total } \\
\text { directors of firm } j \text { in year } t\end{array}$ \\
\hline \multicolumn{3}{|c|}{ Control variables - accruals management specific } \\
\hline $\operatorname{Big} 4_{j, t}$ & Large four audit firms & $\begin{array}{l}\text { Dummy variable, } 1 \text { if } \mathrm{j} \text { firm is audited by Big } 4 \\
\text { auditors, } 0 \text { otherwise }\end{array}$ \\
\hline Litigation $_{\mathrm{j}, \mathrm{t}}$ & The risk of security litigation & $\begin{array}{l}\text { Dummy variable, } 1 \text { if } \mathrm{j} \text { firm is in } \\
\text { pharmaceuticals/biotechnology, software, or } \\
\text { services industries, } 0 \text { otherwise }\end{array}$ \\
\hline \multicolumn{3}{|c|}{ Control variables - underlying earnings specific } \\
\hline Meet $_{j, t}$ & Meeting earnings targets & $\begin{array}{l}\text { Dummy variable that equals } 1 \text { if } \mathrm{j} \text { firm's } \\
\text { earnings before tax in year } \mathrm{t} \text { is greater than or } \\
\text { equal to earnings before tax in year } \mathrm{t}-1 \text {, and } 0 \\
\text { otherwise }\end{array}$ \\
\hline
\end{tabular}




\begin{tabular}{|c|c|c|}
\hline $\operatorname{Loss}_{\mathrm{j}, \mathrm{t}}$ & Earnings loss situation & $\begin{array}{l}\text { Dummy variable that equals } 1 \text { if } \mathrm{j} \text { firm reports } \\
\text { statutory earnings in year } t \text {, and } 0 \text { otherwise }\end{array}$ \\
\hline \multicolumn{3}{|c|}{ Control variables - general } \\
\hline$P E_{j, t}$ & The growth potential of the firm & Price-to-earnings ratio for $\mathrm{j}$ firm in year $\mathrm{t}$ \\
\hline $\mathrm{PB}_{\mathrm{j}, \mathrm{t}}$ & $\begin{array}{l}\text { The extent of over- or under-valuation } \\
\text { of stock price }\end{array}$ & Price-to-book ratio for $\mathrm{j}$ firm in year $\mathrm{t}$ \\
\hline $\mathrm{PBPE}_{\mathrm{j}, \mathrm{t}}$ & $\begin{array}{l}\text { Average of price-to-earnings ratio and } \\
\text { price-to-book ratio }\end{array}$ & $\begin{array}{l}\text { The average of } \mathrm{PE}_{\mathrm{j}, \mathrm{t}} \text { and } \mathrm{PB}_{\mathrm{j}, \mathrm{t}} \text { for firm } \mathrm{j} \text { in year } \\
\mathrm{t}\end{array}$ \\
\hline Leverage $_{\mathrm{j}, \mathrm{t}}$ & Ability to meet financial obligations & $\begin{array}{l}\text { Short-term and long-term debt divided by total } \\
\text { assets for firm } \mathrm{j} \text { in year } \mathrm{t}\end{array}$ \\
\hline SalesG $\mathrm{G}_{\mathrm{j}, \mathrm{t}}$ & Sales growth & $\begin{array}{l}\text { Sales for firm } j \text {, year } t \text { minus the sales for firm } \\
j \text {, year } t-1 \text {, then divided by the sales for firm } j \text {, } \\
\text { in year } t\end{array}$ \\
\hline MtoB $_{j, t}$ & Firm growth & Market-to-book equity ratio for firm $\mathrm{j}$, in year $\mathrm{t}$ \\
\hline Mktcap $_{\mathrm{j}, \mathrm{t}}$ & A market-based firm size & $\begin{array}{l}\text { Natural logarithm of the market capitalisation } \\
\text { of the firm at the beginning of year } t \text { for firm } j\end{array}$ \\
\hline $\mathrm{NOA}_{\mathrm{j}, \mathrm{t}}$ & $\begin{array}{l}\text { The extent of earnings management in } \\
\text { previous periods using accruals }\end{array}$ & $\begin{array}{l}\text { Shareholders' equity less cash and cash } \\
\text { equivalent plus total debt at the beginning of } \\
\text { the year divided by lagged sales for firm } j\end{array}$ \\
\hline $\mathrm{ROE}_{\mathrm{j}, \mathrm{t}}$ & Profitability of firm & $\begin{array}{l}\text { Earnings before tax divided by average equity } \\
\text { for firm } \mathrm{j} \text { in year } \mathrm{t}\end{array}$ \\
\hline Capital $_{\mathrm{j}, \mathrm{t}}$ & $\begin{array}{l}\text { Ability to use assets to generate } \\
\text { revenue }\end{array}$ & $\begin{array}{l}\text { Capital intensity measured by the ratio of net } \\
\text { book value of property, plant, and equipment } \\
\text { to total assets for firm } \mathrm{j} \text { in year } \mathrm{t}\end{array}$ \\
\hline
\end{tabular}




\section{Appendix two}

Examples of firms that conform to/ do not conform to the underlying earnings disclosure guidelines ${ }^{12}$

\begin{tabular}{|l|l|}
\hline Firms that conform to guidelines & Firms that do not conform to guidelines \\
\hline Rio Tinto Limited & Fortescue Metals Group Ltd \\
\hline Brambles Limited & Sydney Airport \\
\hline Boral Limited & Fletcher Building Limited \\
\hline AWE Limited & Mineral Resources Limited \\
\hline Beach Energy Limited & \\
\hline BlueScope Steel Limited & Sigma Healthcare Limited \\
& \\
\hline
\end{tabular}

\footnotetext{
${ }^{12}$ The annual reports were collected from DatAnalysis Premium database.
} 